\title{
Chemistry of Bis(aryloxo)palladium(II) Complexes with N-Donor Ligands: Structural Features of the Palladium-to-Oxygen Bond and Formation of $\mathrm{O}-\mathrm{H} \cdots \mathrm{O}$ Bonds
}

\author{
Gerardus M. Kapteijn, ${ }^{\dagger}$ David M. Grove, ${ }^{\dagger}$ Huub Kooijman, ${ }^{\dagger}$ Wilberth J. J. Smeets, ${ }^{\dagger}$ \\ Anthony L. Spek, ${ }^{\ddagger, \S}$ and Gerard van Koten*, ${ }^{*}$
}

Department of Metal-Mediated Synthesis, Debye Institute, and Crystal and Structural Chemistry, Bijvoet Center for Biomolecular Research, Utrecht University, Padualaan 8, $3584 \mathrm{CH}$, Utrecht, The Netherlands

Received May 11, $1995^{\otimes}$

\begin{abstract}
Reaction of palladium acetate with 2 equiv of sodium phenoxide in the presence of a chelate diamine ligand affords the complexes $\left[\mathrm{Pd}(\mathrm{OPh})_{2}(\mathrm{~N} \sim \mathrm{N})\right](\mathrm{N} \sim \mathrm{N}=$ bpy (1), tmeda (2), teeda (3), dpe (4), dmap (5)). These yellow to orange bis(phenoxo)palladium(II) complexes are thermally stable at room temperature in the solid state as well as in solution. Addition of an excess of pentafluorophenol to $\mathbf{1}, \mathbf{2}, \mathbf{4}$, and $\mathbf{5}$ affords crystalline complexes $\left[\operatorname{Pd}\left(\mathrm{OC}_{6} \mathrm{~F}_{5}\right)_{2}(\mathrm{~N} \sim \mathrm{N})\right](\mathrm{N} \sim \mathrm{N}=$ bpy (6), tmeda (7), dpe (8), dmap (9)). Crystals of $\mathbf{1}$ and $\mathbf{6}$ have been subjected to X-ray diffraction studies. Crystals of $\mathbf{1}$ are orthorhombic, space group $P 2_{1} 2_{1} 2_{1}$ (no. 19), with $a=6.7655(6)$ $\AA, b=16.0585(10) \AA, c=16.7275(13) \AA$, and $Z=4$. Crystals of $\mathbf{6}$ are triclinic, space group $P \overline{1}$ (no. 2 ), with $a=7.567(4) \AA, b=12.708(3) \AA, c=12.912(5) \AA, \alpha=61.51(3)^{\circ}, \beta=74.74(4)^{\circ}, \gamma=88.78(4)^{\circ}$, and $Z=2$. The molecular structures of $\mathbf{1}$ and $\mathbf{6}$ show them to be square-planar complexes, and the main structural difference between these complexes is the orientation of the aromatic rings. In 6 the $\mathrm{OC}_{6} \mathrm{~F}_{5}$ ligands are almost parallel in a face-to-face orientation ( $\pi-\pi$ stacking interactions), whereas in $\mathbf{1}$ the $\mathrm{OC}_{6} \mathrm{H}_{5}$ units are skewed away from each other. An unexpected "mixed" alkoxo(aryloxo) complex $\left[\mathrm{Pd}\left(\mathrm{OCH}\left(\mathrm{CF}_{3}\right)_{2}\right)(\mathrm{OPh})(\mathrm{bpy})\right] \cdot \mathrm{HOPh}(\mathbf{1 0})$ is formed when $\mathbf{1}$ is reacted with 1,1,1,3,3,3-hexafluoro-2-propanol. The molecular structure of $\mathbf{1 0}$ shows $\mathrm{O}-\mathrm{H} \cdots \mathrm{O}$ hydrogen bonding $(\mathrm{O} \cdots \mathrm{O}=2.642(8) \AA)$ between the hydroxyl hydrogen of phenol and the oxygen atom of the phenoxide ligand as well as an additional $\mathrm{C}-\mathrm{H} \cdots \mathrm{O}$ contact $(\mathrm{C} \cdots \mathrm{O})=2.95(1) \AA)$, which can be regarded as the initial stage of a base-assisted $\beta$-hydrogen elimination. Crystals of $\mathbf{1 0}$ are monoclinic, space group $P 2{ }_{1} / c$, with $a=8.3241$ (14) $\AA, b=11.0316(17) \AA, c=26.376(3) \AA, \alpha=93.01(1)^{\circ}, Z=4$. Spectroscopic data of complexes 1-10 indicate that the oxygen atom of the aryloxide or alkoxide ligand is extremely electron-rich, leading to high polarization of the palladium-to-oxygen bond. The bis(phenoxide) complexes $\mathbf{1}, \mathbf{2}$, and $\mathbf{4}$ associate with two molecules of phenol through $\mathrm{O}-\mathrm{H} \cdots \mathrm{O}$ hydrogen bonds to form adducts $\left[\mathrm{Pd}(\mathrm{OPh})_{2}(\mathrm{~N} \sim \mathrm{N})\right] \cdot 2 \mathrm{HOPh}(\mathrm{N} \sim \mathrm{N}=$ bpy (11), tmeda (12), dpe (13)). The palladium complexes $6-9$ with $\mathrm{OC}_{6} \mathrm{~F}_{5}$ groups show no tendency to form adducts with alcohols.
\end{abstract}

\section{Introduction}

The chemistry of late transition metal alkoxides and aryloxides has recently attracted attention, ${ }^{1}$ because it has been discovered that they have unique chemical reactivities which include insertion of small molecules into the metal-to-oxygen bond, ${ }^{2}$ formation of $\mathrm{C}-\mathrm{O}$ bonds, ${ }^{3}$ and association with alcohols through $\mathrm{O}-\mathrm{H} \cdots \mathrm{O}$ hydrogen bonding. ${ }^{4}$ Extensive work has been published on alkoxo and aryloxo derivatives of group 3-6 transition metals. ${ }^{5}$ Unfortunately, the synthesis and reactivity

\footnotetext{
* To whom correspondence should be addressed.

$\dagger$ Debye Institute.

\$ Bijvoet Center for Biomolecular Research.

$\$$ Address correspondence regarding the crystallography to this author.

${ }^{\otimes}$ Abstract published in Advance ACS Abstracts, December 1, 1995.

(1) Bryndza, H. E.; Tam, W. Chem. Rev. 1988, 88, 1163.

(2) For insertion of $\mathrm{CX}\left(\mathrm{X}=\mathrm{O}, \mathrm{O}_{2}\right.$, or $\left.\mathrm{S}_{2}\right)$ into the metal-to-oxygen bond, see: (a) Kim, Y.-J.; Osakada, K.; Sugita, K.; Yamamoto, T.; Yamamoto, A. Organometallics 1988, 7, 2182. (b) Hartwig, J. F.; Bergman, R. G.; Andersen, R. A. J. Am. Chem. Soc. 1991, 113, 6499. (c) Mandal, S. K.; Ho, D. M.; Orchin, M. Organometallics 1993, 12, 1714. (d) Tsuji, J.; Mandai, T. J. Organomet. Chem. 1993, 451, 15. (e) Smith, J. D.; Hansson, B. E.; Merola, J. S.; Waller, F. J. Organometallics 1993, 12, 568. (f) Tóth, I.; Elsevier, C. J. J. Chem. Soc., Chem. Commun. 1993, 529.
}

(3) (a) Glueck, D. S.; Newman Winslow, L. J.; Bergman, R. G. Organometallics 1991, 10, 1462. (b) Thompson, J. S.; Randall, S. L.; Atwood, J. D. Organometallics 1991, 10, 3906. (c) Alsters, P. L.; Boersma, J.; van Koten, G. Tetrahedron Lett. 1991, 32, 675. (d) Thompson, J. S.; Bernard, K. A.; Rappoli, B. J.; Atwood, J. D. Organometallics 1990, 9, 2727. (e) Alsters, P. L.; Boersma, J.; Smeets, W. J. J.; Spek, A. L.; van Koten, G. Organometallics 1993, 12, 1639. of late transition metal alkoxides and aryloxides have been relatively less explored, probably because it was thought that the metal-to-oxygen bond would be weak (due to a mismatch of the hard, basic OR ligands with a "soft" group 7-10 ("platinum group") metal center and therefore difficult to study. ${ }^{6}$ However, Bäckvall et al. have shown using theoretical calculations that the metal-to-oxygen bond is of comparable strength or stronger than the metal-to-carbon $\left(\mathrm{sp}^{3}\right)$ bond. ${ }^{7}$ One difficulty in isolating metal alkoxide complexes is the ease with

(4) (a) Kim, Y.-J.; Osakada, K.; Takenaka, A.; Yamamoto, A. J. Am. Chem. Soc. 1990, 112, 1096. (b) Kegley, S. E.; Schaverien, C. J.; Freudenberger, J. H.; Bergman, R. G.; Nolan, S. P.; Hoff, C. D. J. Am. Chem. Soc. 1987, 109, 6563. (c) Koelle, U.; Wang, M. H.; Raabe, G. Organometallics 1991, 10, 2573. (d) Osakada, K.; Oshiro, K.; Yamamoto, A. Organometallics, 1991, 10, 404. (e) Sone, T.; Iwata, M.; Kasuga, N.; Komiya, S. Chem. Lett. 1991, 1949. (f) Osakada, K.; Kim, K.-Y.; Yamamoto, A. J. Organomet. Chem. 1990, 382, 303. (g) Seligson, A. L.; Cowan, R. L.; Trogler, W. C. Inorg. Chem. 1991 , 30, 3371. (h) Simpson, R. D.; Bergman, R. G. Organometallics 1993, 12, 781. (i) Ozawa, F.; Yamagami, I.; Yamamoto, A. J. Organomet. Chem. 1994, 473, 265.

(5) (a) Bradley, D. C.; Mehrotra, R. C.; Gauer, D. P. Prog. Inorg. Chem. 1960, 2, 203. (b) Bradley, D. C. Metal Alkoxides; Academic: London, 1978. (c) Mehrotra, R. C.; Agarwal, S. K.; Singh, Y. P. Coord. Chem. Rev. 1985, 68, 101. (d) Mehrotra, R. C. Inorg. Chim. Acta, Rev. 1967, $1,99$.

(6) (a) Pearson, R. G. J. Am. Chem. Soc. 1963, 85, 3533; (b) Hartley, F R. The Chemistry of Platinum and Palladium, Wiley: New York, 1973; p 169. (c) Barnard, C. F. J.; Russel, M. J. H. In Comprehensive Coordination Chemistry; Wilkinson, G., Ed.; Pergamon Press: Oxford, 1987; Vol. 6, p 1112. (d) Cotton, F. A.; Wilkinson, G. Advanced Inorganic Chemistry, 5th ed.; Wiley: New York, 1988; p 924. 
which they decompose to metal hydrides, presumably by a $\beta$-hydrogen elimination, and this characteristic is the basis of a classical route for the preparation of metal hydrides. ${ }^{8}$ A weak metal-to-oxygen bond should lower the intrinsic barrier to a $\beta$-hydrogen elimination reaction by raising the ground-state free energy of the metal alkoxide relative to the corresponding metal alkyl. For example, whereas the dimethoxide complexes $\left[\mathrm{Pt}(\mathrm{OMe})_{2}(\mathrm{dppe})\right]$ and $\left[\mathrm{Pd}(\mathrm{OMe})_{2}(\mathrm{bpy})\right]^{9}$ decompose readily at room temperature, the analogous dialkyl complex $\left[\mathrm{Pt}(\mathrm{Et})_{2}(\mathrm{dppe})\right]$ requires temperatures in excess of $150{ }^{\circ} \mathrm{C}$ for slow decomposition. ${ }^{8 \mathrm{~b}}$ Mayer proposed that this reactivity arises from antibonding $\pi$-interactions between lone pairs on the oxygen atom and the filled metal d-orbitals and the consequent formation of quite polar metal-to-oxygen bonds. ${ }^{10}$

An important reason for recent interest in late transition metal alkoxides is that they have been postulated as key intermediates in various metal-catalyzed synthetic organic reactions. ${ }^{11}$ Recent examples include the methoxycarbonylation of alkynes ${ }^{12}$ and the perfectly alternating copolymerization of $\mathrm{CO}$ and olefins. ${ }^{13}$ Results so far obtained with late transition metal alkoxides suggest a rich and varied catalytic chemistry for such complexes, and there is a great demand for structural and mechanistic information to supplement the limited data available. In a continuation of our study of N-donor-ligated alkoxopalladium(II) complexes, ${ }^{14}$ we now report the synthesis, properties, and reactivity of a new class of palladium(II) complexes which contain bidentate $\mathrm{N}$-donor ligands with either two aryloxide groups or one alkoxide in combination with one aryloxide. These complexes readily form adducts with various alcohols, and emphasis is placed on the nature of the $\mathrm{O}-\mathrm{H} \cdots \mathrm{O}$ hydrogen bonding in these species.

\section{Results and Discussion}

Preparation of Bis(aryloxo)palladium(II) Complexes. The 1:2 molar reaction of palladium acetate with sodium phenoxide in the presence of diamine ligands bpy (2,2'-bipyridine), tmeda $\left(N, N, N^{\prime}, N^{\prime}\right.$-tetramethylethylenediamine), teeda $\left(N, N, N^{\prime}, N^{\prime}\right.$-tetraethylethylenediamine), dpe (1,2-dipiperidinoethane) or dmap

(7) (a) Bäckvall, J. E.; Bjorkman, E. E.; Petterson, L.; Siegbahn, R. J. J. Am. Chem. Soc. 1984, 106, 4369. (b) Bäckvall, J. E.; Bjorkman, E. E.; Petterson, L.; Siegbahn, R. J. J. Am. Chem. Soc. 1985, 107, 7265.

(8) (a) Schunn, R. A. In Transition Metal Hydrides; Muetterties, E. L., Ed.; Marcel Dekker: New York, 1971; pp 203-269. (b) Bryndza, H. E.; Calabrese, J. C.; Marsi, M.; Roe, D. C.; Tam, W.; Bercaw, J. E. J. Am. Chem. Soc. 1986, 108, 4805. (c) Bernard, K. A.; Rees, W. M.; Atwood, J. D. Organometallics 1986, 5, 390. (d) Goldman, A. S.; Halpern, J. J. Am. Chem. Soc. 1987, 109, 7537. (e) Hoffman, D. M.; Lappas, D.; Wierda, D. A. J. Am. Chem. Soc. 1993, 115, 10538.

(9) Smith, G. D.; Hanson, B. E.; Merola, J. S.; Waller, F. J. Organometallics 1993, 12, 568 .

(10) Mayer, J. M. Comments Inorg. Chem. 1988, 8, 125.

(11) (a) Heil, B.; Marko, L.; Toros, S. Homogeneous Catalysis with Metal Phosphine Complexes; Pignolet Ed.: New York, 1983; p 329. (b) Yamamoto, A. Organotransition Metal Chemistry; Wiley Interscience: New York, 1986; p 36. (c) Davies, S. G. Organotransition Metal Chemistry: Applications to Organic Syntheses; Pergamon Press: Oxford, 1982; p 348. (d) Paonessa, R. S.; Trogler, W. C. Inorg. Chem. 1983, 22, 1038. (e) Ali, B. E.; Alper, H. J. Org. Chem. 1991, 56, 5357. (f) Ott, J.; Schmid, B.; Venanzi, L. M.; Wang, G.; Ward, T. R. New J. Chem. 1990, 14, 495. (g) Hirose, K.; Keim, W. J. Mol. Catal. 1992, 73, 271. (h) Barbaro, P.; Bianchini, C.; Frediani, P.; Meli, A.; Vizza, F. Inorg. Chem. 1992, 31, 1523.

(12) Drent, E.; Arnoldy, P.; Budzelaar, P. H. M. J. Organomet. Chem. 1993, 455, 247.

(13) Drent, E.; van Broekhoven, J. A. M.; Doyle, M. J. J. Organomet. Chem. 1990, 417, 235.

(14) (a) Alsters, P. L.; Baesjou, P. J.; Janssen, M. D.; Kooijman, H.; Sicherer-Roetman, A.; Spek, A. L.; van Koten, G. Organometallics 1992, 11, 4124. (b) Kapteijn, G. M.; Smeets, W. J. J.; Spek, A. L.; Grove, D. M.; van Koten, G. Inorg. Chim. Acta 1993, 207, 131. (c) Kapteijn, G. M.; Dervisi, A.; Grove, D. M.; Lakin, M. T.; Kooijman, H.; Spek, A. L.; van Koten, G. J. Am. Chem. Soc. 1995, 117, 10939.

\section{Chart 1}<smiles>C1=CC2=C3C=CC=CN3[Pb](Oc3ccccc3)(Oc3ccccc3)N2C=C1</smiles>

1: $N \sim N=$ bpy

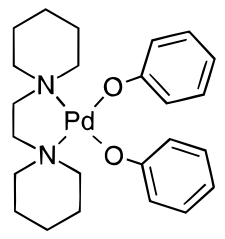

4: $N \sim N=$ dpe

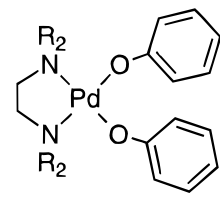

2: $\mathrm{N} \sim \mathrm{N}=$ tmeda $(\mathrm{R}=\mathrm{Me})$ 3: $\mathrm{N} \sim \mathrm{N}=$ teeda $(\mathrm{R}=\mathrm{Et})$

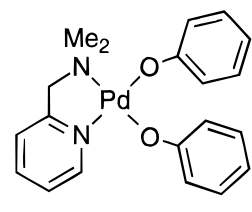

5: $\mathrm{N} \sim \mathrm{N}=\mathrm{dmap}$

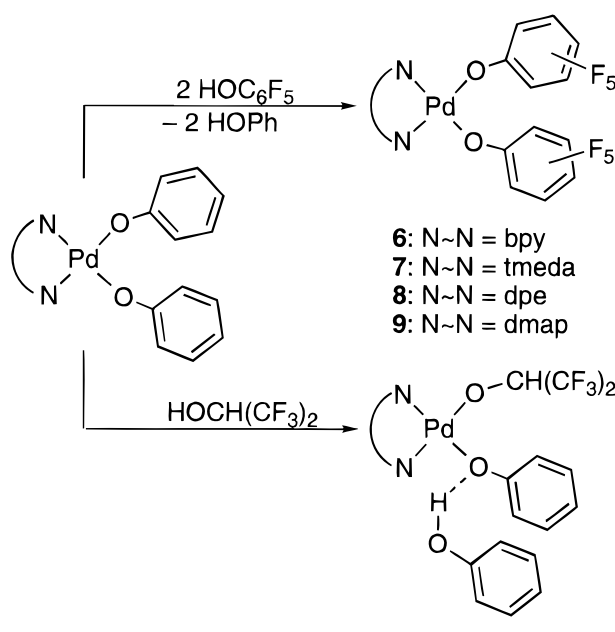

10: $\mathrm{N} \sim \mathrm{N}=$ bpy
Figure 1. Reaction of bis(phenoxo)palladium complexes with pentafluorophenol or $\mathrm{HOCH}\left(\mathrm{CF}_{3}\right)_{2}$.

(2-((dimethylamino)methyl)pyridine) at room temperature affords yellow to orange, crystalline complexes $\left[\mathrm{Pd}(\mathrm{OPh})_{2}(\mathrm{~N} \sim \mathrm{N})\right]$ $(\mathrm{N} \sim \mathrm{N}=$ bpy (1), tmeda (2), teeda (3), dpe (4), dmap (5)) (see Chart 1).

The new bis(phenoxo)palladium(II) complexes $\mathbf{1 - 5}$ have been isolated in high yields $(>85 \%)$ and are thermally stable at room temperature in the solid state as well as in solution. The decomposition temperature in the solid state for these complexes is $>170{ }^{\circ} \mathrm{C}$ without a melting point. In reactions with pentafluorophenol $\left(\mathrm{p} K_{\mathrm{a}}=5.5\right)$, being more acidic than phenol $\left(\mathrm{p} K_{\mathrm{a}}=9.9\right)$, complexes 1, 2, 4, and 5 undergo quantitative substitution of the phenoxide anions for $\mathrm{C}_{6} \mathrm{~F}_{5} \mathrm{O}^{-}$ to afford the corresponding fluorinated bis(aryloxo)palladium complexes $\left[\mathrm{Pd}\left(\mathrm{OC}_{6} \mathrm{~F}_{5}\right)_{2}(\mathrm{~N} \sim \mathrm{N})\right](\mathrm{N} \sim \mathrm{N}=$ bpy (6), tmeda (7), dpe (8), dmap (9)) (see Figure 1).

These complexes have been isolated in high yields $(>90 \%)$ as yellow, crystalline solids, and they are stable at room temperature in the solid state as well as in solution. The melting points (decomposition) for 6-9 are significantly higher by about $30{ }^{\circ} \mathrm{C}$ than those of the corresponding nonfluorinated complexes, and this result indicates the stabilizing effect of electronegative substituents on the aromatic ring (vide infra). The synthesis of the fluorinated bis(aryloxo)palladium complexes 6-9 from bis(phenoxo)palladium complexes is remarkable in that the liberated phenol does not associate to 6-9 to form adducts through intramolecular $\mathrm{O}-\mathrm{H} \cdots \mathrm{O}$ hydrogen bonding with the oxygen atom of the pentafluorophenoxide ligands. However, the phenoxide complexes $\mathbf{1}-\mathbf{5}$ do form $\mathrm{O}-\mathrm{H} \cdots \mathrm{O}$ hydrogen-bonded 
adducts with phenol molecules (vide infra). Adduct formation with alcohols is considered to be a general property of late transition metal alkoxide complexes, ${ }^{4}$ and in earlier studies we found that in the molecular structures of the $\mathrm{N}$-donor-ligated phenoxopalladium(II) complexes trans-[ $\left.\mathrm{Pd}(\mathrm{OPh})_{2}(\text { pyrrolidine })_{2}\right] \cdot-$ $2 \mathrm{HOPh}^{14 \mathrm{a}}$ and $[\mathrm{Pd}(\mathrm{Me})(\mathrm{OPh})(\mathrm{tmeda})] \cdot \mathrm{HOPh}^{14 \mathrm{c}}$ the phenol molecules are indeed associated through $\mathrm{O}-\mathrm{H} \cdots \mathrm{O}$ hydrogen bonds.

The complex $\left[\mathrm{Pd}(\mathrm{OPh})_{2}(\mathrm{bpy})\right]$ (1) shows an interesting reactivity toward an excess of 1,1,1,3,3,3-hexafluoro-2-propanol $\left(\mathrm{p} K_{\mathrm{a}}=9.3\right)$, with which it reacts to afford an unusual "mixed" alkoxo(aryloxo)palladium(II) complex, $\left[\mathrm{Pd}\left(\mathrm{OCH}\left(\mathrm{CF}_{3}\right)_{2}\right)(\mathrm{OPh})-\right.$ (bpy)] $\cdot \mathrm{HOPh}(\mathbf{1 0}) .{ }^{14 \mathrm{~b}}$ This complex is the first example of a late transition metal complex with both an alkoxide and an aryloxide ligand. We believe that the reason that the remaining $\mathrm{OC}_{6} \mathrm{H}_{5}$ unit in $\mathbf{1 0}$ is not substituted for $\mathrm{OCH}\left(\mathrm{CF}_{3}\right)_{2}$ under the reaction conditions employed is due to the combined stabilizing effect of the $\mathrm{O}-\mathrm{H} \cdots \mathrm{O}$ and $\mathrm{C}-\mathrm{H} \cdots \mathrm{O}$ hydrogen bonds.

In this area of chemistry, it is clear that alkoxide and aryloxide complexes can be formed with very different characteristics, and it is therefore worth summarizing at this point the bonding description of alkoxide and aryloxide palladium(II) complexes. In square-planar $\mathrm{Pd}^{\mathrm{II}}$ species containing monoanionic $\mathrm{RO}^{-}$ ligands, the metal center has a total of 16 valency electrons. The $\mathrm{RO}^{-}$ligand forms a $\sigma$-bond from the oxygen to the metal, and this bond will be strongly influenced by the nature of the trans ligand. In general one can expect a ligand with a high trans influence to lengthen the $\mathrm{M}-\mathrm{O}$ bond, whereas one with a low trans influence should shorten this bond. This $\mathrm{M}-\mathrm{O}$ bond could in principle be strengthened (i.e. gain double bond character) if $\pi$-donation from the lone pairs on oxygen to the metal is promoted. This situation could arise, for example, if the metal center has a low number of d-electrons; however, for late transition metals $\pi$-back-donation is expected to be of little importance and repulsion between the lone pairs on oxygen and filled metal d-orbitals is likely to destabilize the $\mathrm{M}-\mathrm{OR}$ bonding. The nature of the $\mathrm{R}$ substituent (either alkyl or aryl) will effect the electron density of the oxygen atom and hence the stability of the $\mathrm{M}-\mathrm{O}$ bond. With alkyl substituents the density at oxygen will remain high and the $\mathrm{M}-\mathrm{O} \sigma$-bond will be enhanced, as will competitive repulsive effects. In contrast, aryl groups are able to delocalize some of the electron density at oxygen into the ring systems, and although this will not effect the $\mathrm{M}-\mathrm{O} \sigma$-bond too much, it will decrease destabilizing effects of the oxygen lone pairs. If the rings bear electronegative substituents (e.g. fluorine atoms), there appears to be a contraction of the oxygen atomic orbitals that not only yields systematically shorter $\mathrm{C}-\mathrm{O} \sigma$-bonds (i.e. there is increased $\pi$-donation from oxygen to the fluorinated aromatic ring) but also lowers the donating ability of the oxygen atom toward the metal center. This increased $\pi$-donation from the oxygen atom to the fluorinated aromatic ring will increase the double bond character of the $\mathrm{C}-\mathrm{O}$ bond (see Figure 2) and thereby produce larger

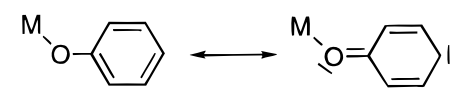

Figure 2. $\pi$-Donation from oxygen to the aromatic ring.

$\mathrm{M}-\mathrm{O}-\mathrm{C}$ angles. One anticipates different structural and spectroscopic characteristics for $\mathrm{C}_{6} \mathrm{H}_{5} \mathrm{O}^{-}$and $\mathrm{C}_{6} \mathrm{~F}_{5} \mathrm{O}^{-}$, and that is indeed what we find.

Molecular Structures of 1, 6, and 10. Figures 3 and 4 show the molecular structures of the bis(aryloxide) complexes [Pd$\left.(\mathrm{OPh})_{2}(\mathrm{bpy})\right](\mathbf{1})$ and $\left[\mathrm{Pd}\left(\mathrm{OC}_{6} \mathrm{~F}_{5}\right)_{2}(\mathrm{bpy})\right](\mathbf{6})$ and the aryloxo(alkoxo) complex $\left[\mathrm{Pd}\left(\mathrm{OCH}\left(\mathrm{CF}_{3}\right)_{2}\right)(\mathrm{OPh})(\mathrm{bpy})\right] \cdot \mathrm{HOPh}(\mathbf{1 0})$, respectively. Selected bond lengths and angles for $\mathbf{1}$ and $\mathbf{6}$ are summarized in Table 1.
In the bis(aryloxo)palladium(II) complexes $\mathbf{1}$ and $\mathbf{6}$, the environments at the metal centers are similar, and the structures offer a unique opportunity for studying the effects related to the nature of the aryloxide ligands. Both complexes possess an approximate square-planar coordination geometry with adjacent interligand angles around the palladium centers falling in the range $80.6(2)-97.8(2)^{\circ}$. In complex 1 in which the aryloxide ligands are trans to the $\mathrm{N}$-donors, the $\mathrm{Pd}-\mathrm{O}$ distances are 1.996(7) and 1.983(6) $\AA$. In related phenoxopalladium(II) complexes having either $\mathrm{P}$ or $\mathrm{O}$ ligands trans to the aryloxide unit, the corresponding distances are shorter by $\sim 0.10 \AA .1,4 a, d$ The main structural difference between $\mathbf{1}$ and $\mathbf{6}$ concerns the orientation of the aryloxide ligands: in $\mathbf{6}$ the fluorinated aryloxide ligands are almost parallel $\left(7.0(2)^{\circ}\right)$ to each other, whereas in $\mathbf{1}$ the phenoxide ligands are skewed away from each other $\left(72.5(5)^{\circ}\right)$. An explanation, using a variety of empirical models, for the nonbonded intramolecular contacts between the aryloxide rings $(\pi-\pi$ stacking) in $\mathbf{6}$ is presented in detail in another paper. ${ }^{15}$ From this latter study it was concluded that the origin for the difference between the two bis(aryloxide) systems $\mathbf{1}$ and $\mathbf{6}$ lies in the electrostatic interactions between the aromatic rings. Stacking interactions are unfavorable for two phenyl groups (as in 1) owing to repulsive electrostatic interactions between the $\pi$-electron densities. Fluorine substituents (as in 6) reduce the effective electron density on the rings, which lowers the $\pi$-electron repulsion to allow attractive dipole-dipole interactions.

A single crystal X-ray diffraction study of the adduct complex $\left[\mathrm{Pd}\left(\mathrm{OCH}\left(\mathrm{CF}_{3}\right)_{2}\right)(\mathrm{OPh})(\mathrm{bpy})\right] \cdot \mathrm{HOPh}(\mathbf{1 0})$ (see Figure 4) shows it to have a square-planar coordination geometry similar to those found in the crystal structures of the bis(aryloxo)palladium complexes 1 and 6 . Complex 10 contains two different anionic ligands, namely $\mathrm{C}_{6} \mathrm{H}_{5} \mathrm{O}^{-}$and $\left(\mathrm{CF}_{3}\right)_{2} \mathrm{CHO}^{-}$, and this is, therefore, the first structurally characterized mixed alkoxo(aryloxo)palladium(II) complex. We reported the molecular structure and X-ray experimental data of $\mathbf{1 0}$ earlier as a communication. ${ }^{14 \mathrm{~b}}$ The $\mathrm{C}-\mathrm{O}$ distance of the phenoxide unit in $\mathbf{1 0}(1.359(10) \AA)$ is similar to the $\mathrm{C}-\mathrm{O}$ distances found in $\mathbf{1}$ and $\mathbf{6}$. This is remarkable as the oxygen atom of the phenoxide ligand in $\mathbf{1 0}$ is associated with a phenol molecule through $\mathrm{O}-\mathrm{H} \cdots \mathrm{O}$ hydrogen bonding $(\mathrm{O} \cdots \mathrm{O}=2.642(8) \AA)$, which should reduce the donating ability of the oxygen toward the metal center. It is known that association of phenol to the palladium aryloxide complexes $\left[\mathrm{Pd}(\mathrm{Me})(\mathrm{OPh})\left(\mathrm{PMe}_{3}\right)_{2}\right]^{4 \mathrm{a}}$ or $[\mathrm{Pd}(\mathrm{Me})(\mathrm{OPh})(\text { tmeda })]^{14 \mathrm{c}}$ can result in lengthening of the $\mathrm{C}-\mathrm{O}$ bond in the aryloxide unit. Another factor that can contribute to a lengthening of the phenoxide $\mathrm{C}-\mathrm{O}$ bond in $\mathbf{1 0}$ is the position of the acidic proton of the $\mathrm{OCH}\left(\mathrm{CF}_{3}\right)_{2}$ group close to the oxygen atom of the phenoxide in what can be seen as a $\mathrm{C}-\mathrm{H} \cdots \mathrm{O}$ interaction $(\mathrm{C} \cdots \mathrm{O}$ $=2.95(1) \AA$ ). It is known that a polarized $\mathrm{C}-\mathrm{H}$ bond can form an electrostatic interaction with the oxygen atom of a phenoxide group and so stabilize the structure as a whole. ${ }^{14 \mathrm{~b}, \mathrm{c}}$ This may be termed a steering interaction which, though small in energy $\left(1-2 \mathrm{kcal} \mathrm{mol}^{-1}\right)$, is sufficient to select a preferred molecular conformation. ${ }^{16}$ In our case this nonbonded $\mathrm{C}-\mathrm{H} \cdots \mathrm{O}$ interaction may be regarded as representing the incipient stage of a base-assisted $\beta$-hydrogen elimination, ${ }^{17}$ involving transfer of the proton from $\mathrm{OCH}\left(\mathrm{CF}_{3}\right)_{2}$ to the oxygen atom of the phenoxide anion that would result in a ketone and a phenol coordinated to the palladium center (see Figure 5). In this context it is worth

(15) Hunter, C. A.; Lu, X.-J.; Kapteijn, G. M.; van Koten, G. J. Chem. Soc., Faraday Trans. 1995, 91, 2009.

(16) Desiraju, G. R. Acc. Chem. Res. 1991, 24, 290.

(17) (a) Bürgi, H. B.; Dunitz, J. D.; Shefter, E. Acta Crystallogr. 1974, B30, 1517. (b) Bürgi, H. B. Angew. Chem., Int. Ed. Engl. 1975, 14 , 460. (c) Dunitz, J. D. Phil. Trans. R. Soc. London 1975, B272, 99. 

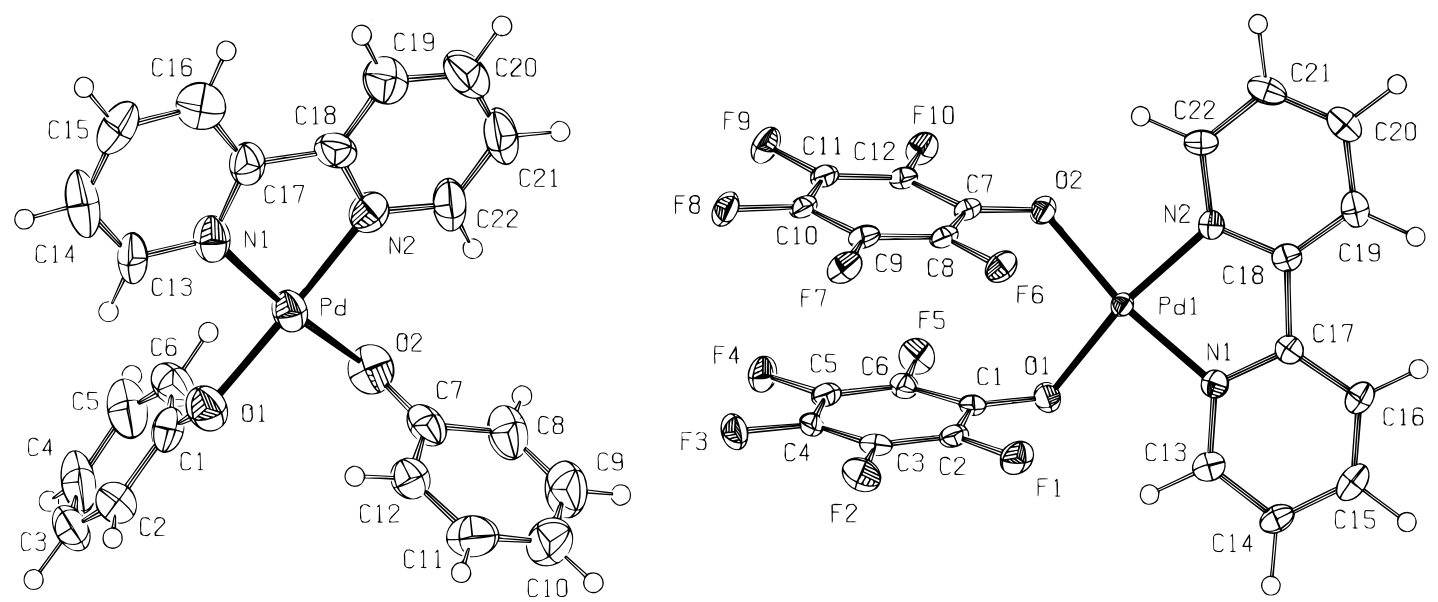

Figure 3. Thermal motion ellipsoid plot (ORTEP, 50\% probability) of the molecular structures of $\left[\mathrm{Pd}(\mathrm{OPh})_{2}(\mathrm{bpy})\right](\mathbf{1})(\mathrm{left})$ and $\left[\mathrm{Pd}\left(\mathrm{OC} \mathrm{F}_{5}\right)_{2}-\right.$ (bpy)] (6) (right) together with the adopted numbering scheme.

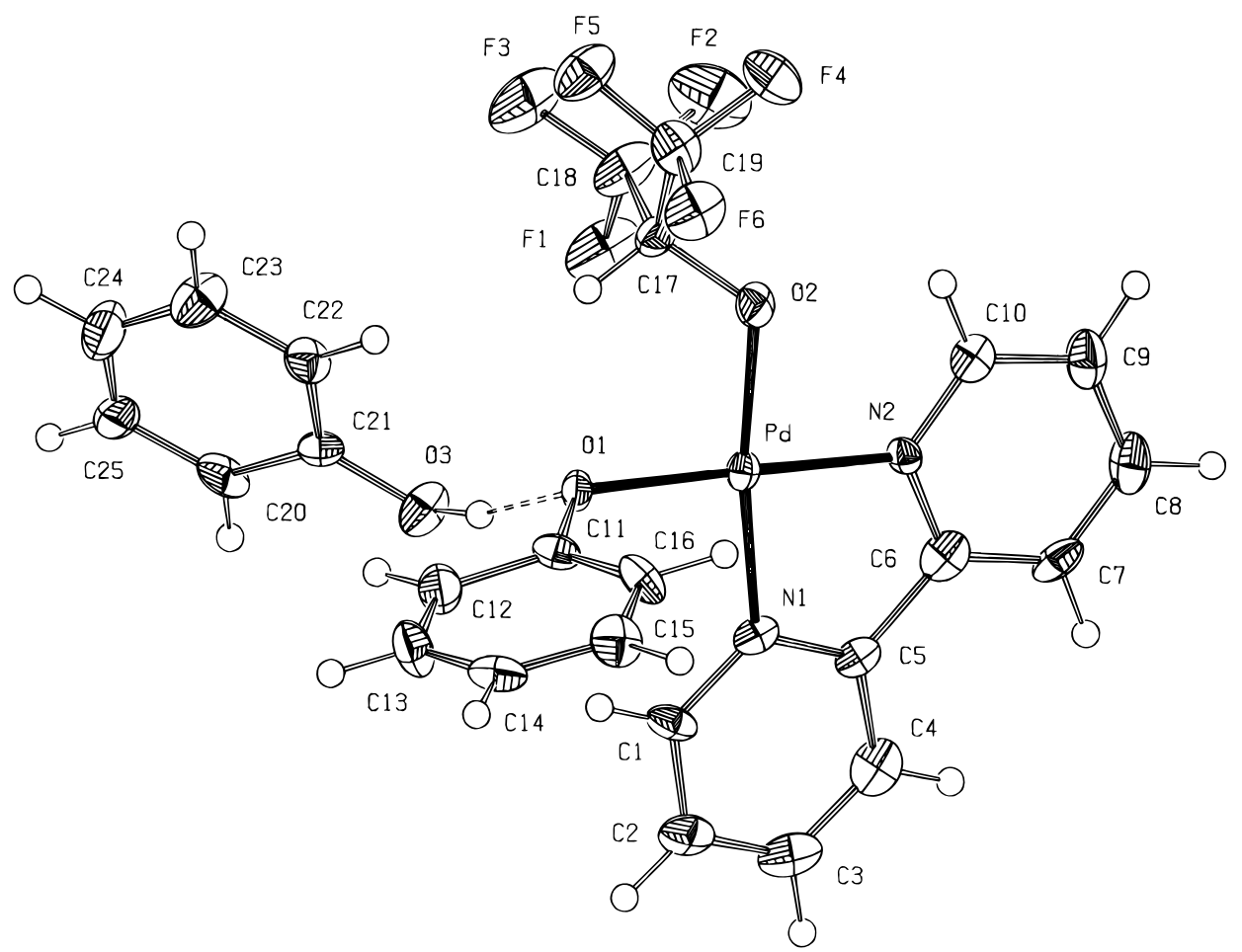

Figure 4. Thermal motion ellipsoid plot (ORTEP, $50 \%$ probability) of the molecular structure of $\left[\mathrm{Pd}\left(\mathrm{OCH}\left(\mathrm{CF}_{3}\right)_{2}(\mathrm{OPh})(\mathrm{bpy})\right] \cdot \mathrm{HOPh}(\mathbf{1 0})\right.$ together with the adopted numbering scheme.

Table 1. Relevant Bond Lengths (A) and Bond Angles (deg) for the Aryloxide Complexes $\mathbf{1}$ and $\mathbf{6}^{a}$

\begin{tabular}{|c|c|c|c|c|c|}
\hline & 1 & 6 & & 1 & 6 \\
\hline \multicolumn{6}{|c|}{ Bond Lengths } \\
\hline $\mathrm{Pd}-\mathrm{O}(1)$ & $1.996(7)$ & $2.013(3)$ & $\mathrm{Pd}-\mathrm{N}(2)$ & $2.013(7)$ & $1.998(5)$ \\
\hline $\mathrm{Pd}-\mathrm{O}(2)$ & $1.983(6)$ & $2.013(4)$ & $\mathrm{C}(1)-\mathrm{O}(1)$ & $1.332(13)$ & $1.309(7)$ \\
\hline $\mathrm{Pd}-\mathrm{N}(1)$ & $2.005(8)$ & $1.989(6)$ & $\mathrm{C}(7)-\mathrm{O}(2)$ & $1.331(13)$ & $1.310(7)$ \\
\hline
\end{tabular}

Bond Angles

$\mathrm{O}(1)-\mathrm{Pd}-\mathrm{O}(2) \quad 93.7(3) \quad 97.78(16) \mathrm{O}(2)-\mathrm{Pd}-\mathrm{N}(2) \quad 93.0(3) \quad 90.59(18)$ $\mathrm{O}(1)-\mathrm{Pd}-\mathrm{N}(1) \quad 92.1(3) \quad 90.56(18) \mathrm{N}(1)-\mathrm{Pd}-\mathrm{N}(2) \quad 81.7(3) \quad 80.6(2)$

$\mathrm{O}(1)-\mathrm{Pd}-\mathrm{N}(2)$ 171.2(3) 170.1(2) $\mathrm{Pd}-\mathrm{O}(1)-\mathrm{C}(1)$ 121.0(7) 123.3(3)

$\mathrm{O}(2)-\mathrm{Pd}-\mathrm{N}(1)$ 172.9(3) 169.93(17) $\mathrm{Pd}-\mathrm{O}(2)-\mathrm{C}(7)$ 119.6(6) 124.8(3)

${ }^{a}$ Estimated standard deviations in the least significant digits are given in parentheses.

noting that complexes with coordinated ketones have recently been proposed as intermediates in palladium-catalyzed acetalization reactions. ${ }^{11 \mathrm{f}}$

The $\mathrm{O} \cdots \mathrm{O}$ distance of $2.642(8) \AA$ in $\mathbf{1 0}$ can be used as a measure of the strength of the $\mathrm{O}-\mathrm{H} \cdots \mathrm{O}$ hydrogen bond.

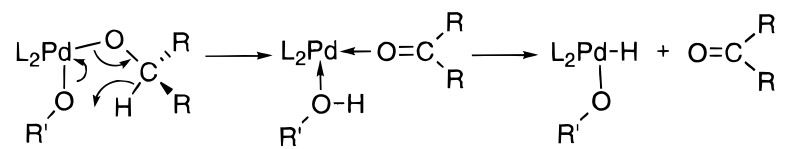

Figure 5. $\beta$-Hydrogen elimination from a fluorinated alkoxide complex.

Literature data shows that the $\mathrm{O}-\mathrm{H} \cdots \mathrm{O}$ bonds between phenols and palladium or platinum alkoxide complexes have $\mathrm{O} \cdots \mathrm{O}$ distances in the range 2.59-2.65 $\AA$, and measured enthalpy values for phenol association are typically -4.1 to $-5.9 \mathrm{kcal}$ $\mathrm{mol}^{-1} \cdot 4 \mathrm{~b}, \mathrm{~d}, \mathrm{f}, 14 \mathrm{a}-\mathrm{c}$ Since the phenol molecule in $\mathbf{1 0}$ is $\mathrm{O}-\mathrm{H} \cdots \mathrm{O}$ hydrogen bonded with the more basic phenoxide $\left(\mathrm{p} K_{\mathrm{a}}=9.9\right)$ ligand and not to the less basic hexafluoroisopropoxide unit $\left(\mathrm{p} K_{\mathrm{a}}\right.$ $=9.3$ ), one can deduce that the reactivity of anionic $\mathrm{RO}^{-}$ligands coordinated to a metal center still follow the concepts of organic acids and bases.

Solid State IR Spectra. The IR spectra of the bis(aryloxo)palladium complexes $\left[\mathrm{Pd}(\mathrm{OAr})_{2}(\mathrm{~N} \sim \mathrm{N})\right](\mathbf{1}-\mathbf{9})$ show a strong absorption in the region $1275-1310 \mathrm{~cm}^{-1}$, which is ascribed 
Table 2. $\mathrm{C}-\mathrm{O}$ Stretching Frequencies for Bis(aryloxo)palladium Complexes $\left[\mathrm{Pd}(\mathrm{OR})_{2}(\mathrm{~N} \sim \mathrm{N})\right]^{a}$

\begin{tabular}{lcc}
\hline & \multicolumn{2}{c}{$v(\mathrm{C}-\mathrm{O})$} \\
\cline { 2 - 3 } $\mathrm{N} \sim \mathrm{N}$ & $\mathrm{R}=\mathrm{C}_{6} \mathrm{H}_{5}$ & $\mathrm{R}=\mathrm{C}_{6} \mathrm{~F}_{5}$ \\
\hline bpy & $1280(\mathbf{1})$ & $1310(\mathbf{6})$ \\
tmeda & $1280(\mathbf{2})$ & $1310(\mathbf{7})$ \\
dpe & $1275(\mathbf{4})$ & $1305(\mathbf{8})$ \\
dmap & $1280(\mathbf{5})$ & $1305(\mathbf{9})$
\end{tabular}

${ }^{a}$ Stretching frequencies are reported in $\mathrm{cm}^{-1}$. IR spectra were recorded in the solid state as $\mathrm{KBr}$ pellets. For comparison: $v(\mathrm{C}-\mathrm{O})$ $\mathrm{PhOH} 1240 \mathrm{~cm}^{-1}$; NaOPh $1320 \mathrm{~cm}^{-1}$.

to the $(\mathrm{M}) \mathrm{O}-\mathrm{C}(\mathrm{Ar})$ stretching vibration $(v(\mathrm{C}-\mathrm{O}))$ of the aryloxide unit (see Table 2). ${ }^{14 a}$ These data contrast with $v(\mathrm{C}-$ $\mathrm{O})$ values for main group and early transition metal phenoxides, which lie considerably lower in the range $1100-1200 \mathrm{~cm}^{-1} \cdot{ }^{18}$ It is known that the $\mathrm{C}-\mathrm{O}$ bond order in transition metal phenoxides varies with the degree of metal-to-oxygen $\mathrm{d}_{\pi}-\mathrm{p}_{\pi}$ bonding, and Auerbach et al. found an increasing frequency (from 1249 to $1298 \mathrm{~cm}^{-1}$ ) with decreasing $\mathrm{d}_{\pi}-\mathrm{p}_{\pi} \mathrm{M}-\mathrm{O}$ bonding, i.e. with increasing number of d-electrons. ${ }^{19}$ The low $v(\mathrm{C}-\mathrm{O})$ values of our new bis(aryloxo)palladium(II) complexes 1-9 are therefore, by analogy, evidence for the absence of $d_{\pi}-$ $\mathrm{p}_{\pi}$ bonding. One also sees that $v(\mathrm{C}-\mathrm{O})$ values of the bis(pentafluorophenoxo)palladium complexes 6-9 are higher than those of the bis(phenoxo)palladium complexes $\mathbf{1 - 5}$, and this would be consistent with a $\mathrm{C}-\mathrm{O}$ bond length in the fluorinated aryloxide complexes that is shorter than in the phenoxide complexes.

NMR of (Aryloxo)palladium Complexes. The ${ }^{1} \mathrm{H}$ NMR data of the complexes $\left[\mathrm{Pd}(\mathrm{OAr})_{2}(\mathrm{~N} \sim \mathrm{N})\right](\mathbf{1}-\mathbf{9})$ are summarized in Table 3. For the bis(phenoxo)complexes $\mathbf{1 - 5}$ at room temperature $\left(\mathrm{CDCl}_{3}\right)$, the ortho, meta, and para protons of the phenoxide ligands afford well-resolved separate resonances with all the ortho protons and all the meta protons being equivalent on the NMR time scale, a situation consistent with rapid rotation of the phenyl group about the $\mathrm{C}-\mathrm{O}$ axis. The ortho protons for these complexes are significantly shifted downfield compared to both free phenol and sodium phenolate, and this characteristic low-field resonance position can be attributed to the bent structure of the $\mathrm{M}-\mathrm{O}-\mathrm{Ph}$ unit $\left(\angle \mathrm{M}-\mathrm{O}-\mathrm{Ar} 121-124^{\circ}\right.$ in the crystal structures of $\mathbf{1}, \mathbf{6}$, and $\mathbf{1 0}$ ). As a result of this, each ortho proton spends a considerable amount of time in a position above the coordination plane of the metal where it is influenced by the magnetic anisotropy of the metal center. ${ }^{20}$ The ${ }^{13} \mathrm{C}$ NMR data of $\mathbf{2 - 5}$ are summarized in Table 4 . The phenoxide ${ }^{13} \mathrm{C}$ NMR chemical shifts of the bis(aryloxo)palladium complexes $\mathbf{2}-\mathbf{5}$ are similar to both those of typical anionic phenoxides like $\mathrm{C}_{6} \mathrm{H}_{5} \mathrm{O}^{-} \mathrm{Na}^{+}$or $\mathrm{C}_{6} \mathrm{H}_{5} \mathrm{O}^{-} \mathrm{NBu}_{4}{ }^{+21}$ and those of analogous palladium and platinum phenoxide complexes. ${ }^{14 a-c}$ In these complexes the large $\sim 13 \mathrm{ppm}$ low-field shift of the ipso carbon atom $(\delta \approx 167 \mathrm{ppm})$ and the significant high-field shift of $\sim 7$ ppm of the para carbon atom $(\delta \approx 114 \mathrm{ppm})$ compared to the shift values for phenol $^{22}$ indicate a strongly polarized $\mathrm{M}-\mathrm{O}$ bond. Due to the presence of a nonsymmetrical nitrogen donor ligand in $\mathbf{5}$, the phenoxide ligands are chemically and magneti-

(18) Malhotra, K. C.; Martin, R. L. J. Organomet. Chem. 1982, $239,159$.

(19) Auerbach, U.; Weyhermüller, T.; Wieghardt, K.; Nuber, B.; Bill, E.; Butzlaff, C.; Trautwein, A. X. Inorg. Chem. 1993, 12, 508.

(20) (a) Miller, R. G.; Stauffer, R. D.; Fahey, D. R.; Farnell, D. R. J. Am. Chem. Soc. 1970, 92, 1511. (b) Albinati, A.; Pregosin, P. S.; Wombacher, F. Inorg. Chem. 1990, 29, 1812.

(21) (a) Kraft, T. E.; Hejna, C. I.; Smith, J. S. Inorg. Chem. 1990, 29, 2682. (b) Noyori, R.; Nishida, I.; Sakata, J. Tetrahedron Lett. 1981, 22, 3993.

(22) Johnson, L. F.; Jankowski, W. C. Carbon-13 NMR Spectra; Wiley: New York, 1972.

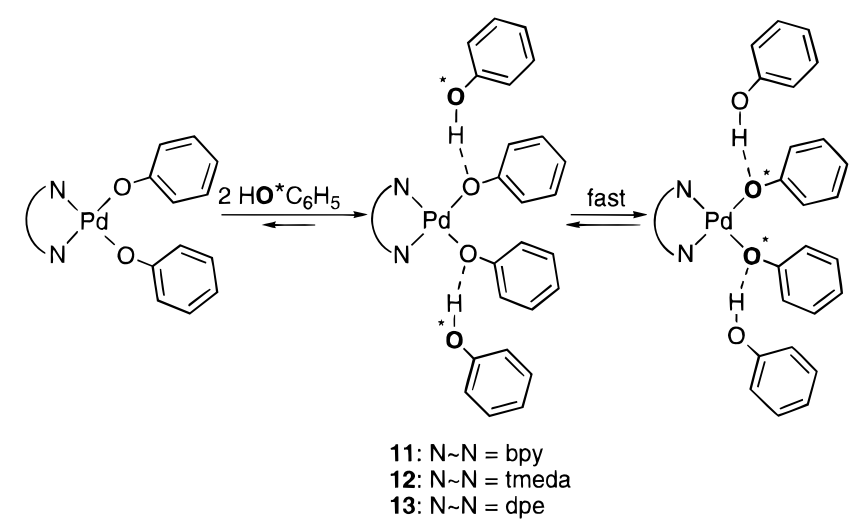

Figure 6. Formation of bis(phenol) adducts and phenoxide-phenol exchange.

cally inequivalent, and this fact is reflected in the presence of two sets of phenoxide carbon resonances in its ${ }^{13} \mathrm{C} N M R$ spectrum $\left(\mathrm{CDCl}_{3}\right)$; i.e. the phenoxide ligand is significantly influenced by the electronic properties of the trans-positioned donor atoms. However, this ligand inequivalence is not seen in the ${ }^{1} \mathrm{H}$ NMR spectrum $(300 \mathrm{MHz})$ of $\mathbf{5}$, where the protons on the two aromatic rings afford one set of resonances.

Solution Behavior of Phenol Adducts (10-13). Addition of 2 equiv of phenol to the bis(phenoxo)palladium complexes 1, 2, and 4 leads to the in situ formation of the bis(phenol) adducts $\left[\mathrm{Pd}(\mathrm{OPh})_{2}(\mathrm{bpy})\right] \cdot 2 \mathrm{HOPh}(\mathbf{1 1}),\left[\mathrm{Pd}(\mathrm{OPh})_{2}\right.$ (tmeda) $] \cdot-$ $2 \mathrm{HOPh}(\mathbf{1 2})$, and $\left[\mathrm{Pd}(\mathrm{OPh})_{2}(\mathrm{dpe})\right] \cdot 2 \mathrm{HOPh}(\mathbf{1 3})$, respectively (see Figure 6), which have been characterized by ${ }^{1} \mathrm{H}$ and ${ }^{13} \mathrm{C}$ NMR. It has not proved possible to isolate $\mathbf{1 1 - 1 3}$ as solids, since attempted isolation by precipitation or crystallization regenerated the starting materials. In the ${ }^{1} \mathrm{H}$ NMR spectra of these latter species and the mono(phenol) adduct 10, the presence of $\mathrm{O}-\mathrm{H} \cdots \mathrm{O}$ hydrogen bonds between the oxygen atom of the phenoxide ligand and the $\mathrm{OH}$ hydrogen of the associated phenol in solution is clearly indicated (vide infra).

In the ${ }^{1} \mathrm{H}$ NMR spectra of $\mathbf{1 2}$ a broad resonance due to the $\mathrm{O}-\mathrm{H}$ hydrogen of the phenol molecules associated to the oxygen atoms of $\left[\mathrm{Pd}(\mathrm{OPh})_{2}(\mathrm{tmeda})\right]$ appears at $c a .7 .5 \mathrm{ppm}$, i.e. at significantly lower field than the $\mathrm{OH}$ hydrogen of noncomplexed phenol at ca. $5.5 \mathrm{ppm}$ in dry $\mathrm{CDCl}_{3}$. A similar low-field shift of the $\mathrm{O}-\mathrm{H}$ hydrogen has also been observed for related late transition metal alkoxide or phenoxide complexes in which an alcohol molecule is associated through strong $\mathrm{O}-\mathrm{H} \cdots \mathrm{O}$ hydrogen bonding with the oxygen atom of an alkoxide or aryloxide ligand. ${ }^{4 a, b, f, 14 a-c}$ However, the resonance position of the $\mathrm{OH}$ hydrogen in $\mathbf{1 1 - 1 3}$ is less shifted to low field than in closely related palladium phenoxide adducts $(\delta=$ 9.5-11.0 ppm), and this, together with the fact that it was not possible to isolate these adducts, is an indication of a weak $\mathrm{O}-\mathrm{H} \cdots \mathrm{O}$ hydrogen bond in 11-13. ${ }^{1} \mathrm{H}$ NMR spectra of the mixed alkoxide aryloxide palladium complex $\mathbf{1 0}$ also reveal the presence of an $\mathrm{OH}$ resonance at low field ( $c a .8 .5 \mathrm{ppm}$ ), which indicates the presence of $\mathrm{O}-\mathrm{H} \cdots \mathrm{O}$ hydrogen bonding in solution.

When a $\mathrm{CDCl}_{3}$ solution of $\mathbf{1 1 - 1 3}$ is heated, the $\mathrm{OH}$ signal shifts to higher field, consistent with a shift of the association equilibrium toward uncomplexed 1, 2, or 4 and free phenol. We made several attempts to determine the equilibrium constants for $\mathrm{O}-\mathrm{H} \cdots \mathrm{O}$ hydrogen bond formation between the cis-bis(phenoxo)palladium complexes $\mathbf{1 - 5}$ and phenol using the Scatchard method, ${ }^{23}$ but due to the low solubility of these complexes in common organic solvents it was not possible to obtain

(23) Joesten, M. D.; Schaad, L. J. Hydrogen Bonding; Marcel Dekker: New York, 1974; p 173. 
Table 3. $\quad{ }^{1} \mathrm{H}$ NMR Data of Palladium Aryloxide Complexes ${ }^{a}$

\begin{tabular}{|c|c|c|}
\hline compound & phenoxide/phenol & $\mathrm{N} \sim \mathrm{N}$ and $\mathrm{HOCH}\left(\mathrm{CF}_{3}\right)_{2}$ \\
\hline $\mathbf{1}^{b}$ & $7.21(\mathrm{~d}, o-H), 6.99(\mathrm{t}, m-H), 6.49(\mathrm{t}, p-H)$ & bpy; $8.72\left(\mathrm{dd}, H_{6}\right), 8.11\left(\mathrm{t}, H_{4}\right), 8.01\left(\mathrm{~d}, H_{3}\right), 7.58\left(\mathrm{td}, H_{5}\right)$ \\
\hline 2 & $7.17(\mathrm{~d}, o-H), 6.98(\mathrm{t}, m-H), 6.46(\mathrm{t}, p-H)$ & tmeda; $2.61\left(\mathrm{~s}, \mathrm{NCH}_{3}\right), 2.56\left(\mathrm{~s}, \mathrm{NCH}_{2}\right)$ \\
\hline 3 & $7.08(\mathrm{~d}, o-H), 6.94(\mathrm{t}, m-H), 6.42(\mathrm{t}, p-H)$ & $\begin{array}{l}\text { teeda; } 3.02\left(\mathrm{~m}, \mathrm{CH}_{2} \mathrm{CH}_{3}\right), 2.61\left(\mathrm{~m}, \mathrm{CH}_{2} \mathrm{CH}_{3}\right), 2.45\left(\mathrm{~s}, \mathrm{NCH}_{2}\right) \text {, } \\
\quad 1.46\left(\mathrm{t}, \mathrm{CH}_{2} \mathrm{CH}_{3}\right)\end{array}$ \\
\hline 4 & $7.15(\mathrm{~d}, o-H), 7.00(\mathrm{t}, m-H), 6.45(\mathrm{t}, p-H)$ & $\begin{array}{l}\text { dpe; } 3.57-3.19\left(\mathrm{~m}, \mathrm{NCH}_{2}\right), 2.87\left(\mathrm{~s}, \mathrm{NCH}_{2}-\mathrm{CH}_{2} \mathrm{~N}\right) \\
\quad 1.72-1.32\left(\mathrm{~m}, \mathrm{CH}_{2}\right)\end{array}$ \\
\hline $\mathbf{5}^{b}$ & $7.16(\mathrm{~d}, o-H), 6.85(\mathrm{t}, m-H), 6.31(\mathrm{t}, p-H)$ & $\begin{array}{l}\mathrm{dmap} ; 8.40\left(\mathrm{~d}, H_{6}\right), 8.09\left(\mathrm{td}, H_{4}\right), 7.66\left(\mathrm{~d}, H_{3}\right), 7.52\left(\mathrm{t}, H_{5}\right), \\
\quad 4.30\left(\mathrm{~s}, \mathrm{CH}_{2}\right), 2.70\left(\mathrm{~s}, \mathrm{CH}_{3}\right)\end{array}$ \\
\hline $6^{b}$ & & bpy; $8.65\left(\mathrm{dd}, H_{6}\right), 8.18\left(\mathrm{t}, H_{4}\right), 8.04\left(\mathrm{~d}, H_{3}\right), 7.62\left(\mathrm{td}, H_{5}\right)$ \\
\hline 7 & & tmeda; $2.60\left(\mathrm{~s}, \mathrm{NCH}_{2}\right), 2.58\left(\mathrm{~s}, \mathrm{NCH}_{3}\right)$ \\
\hline 8 & & $\begin{array}{l}\text { dpe; } 3.58-3.30\left(\mathrm{~m}, \mathrm{NCH} H_{2}\right), 2.97\left(\mathrm{~s}, \mathrm{NCH}_{2}-\mathrm{CH}_{2} \mathrm{~N}\right) \\
\quad 1.81-1.28\left(\mathrm{~m}, \mathrm{CH}_{2}\right)\end{array}$ \\
\hline $\mathbf{9}^{b, c}$ & & $\begin{array}{l}\mathrm{dmap} ; 8.31\left(\mathrm{~d}, H_{6}\right), 8.19\left(\mathrm{td}, H_{4}\right), 7.76\left(\mathrm{~d}, H_{3}\right), 7.60\left(\mathrm{t}, H_{5}\right), \\
\quad 4.48\left(\mathrm{~s}, \mathrm{CH}_{2}\right), 2.81\left(\mathrm{~s}, \mathrm{CH}_{3}\right)\end{array}$ \\
\hline $\mathbf{1 0}^{b, d}$ & $\begin{array}{l}8.5(\mathrm{br} \mathrm{s}, \mathrm{O} H), 7.32(\mathrm{~d}, o-H), 7.07(\mathrm{t}, m-H) \\
\quad 6.57(\mathrm{t}, p-H)\end{array}$ & $\begin{array}{l}\text { bpy; } 8.83\left(\mathrm{dd}, H_{6}\right), 8.47\left(\mathrm{dd}, H_{6}{ }^{\prime}\right), 8.15-8.03\left(\mathrm{~m}, H_{4}, H_{4}{ }^{\prime}\right), \\
\quad 7.98\left(\mathrm{~d}, H_{3}, H_{3}^{\prime}\right), 7.65\left(\mathrm{td}, H_{5}^{\prime}\right), 7.46\left(\mathrm{td}, H_{5}\right) . \\
\mathrm{HOCH}^{\prime}\left(\mathrm{CF}_{3}\right)_{2} ; 4.26(\mathrm{sep}, \mathrm{OC} H)\end{array}$ \\
\hline $\mathbf{1 1}^{b}$ & $\begin{array}{l}7.0(\mathrm{~s}, \mathrm{OH}), 7.25-7.10(\mathrm{~m}, o-H \mathrm{PdOPh}, m-H \mathrm{HOPh}) \\
7.03(\mathrm{t}, m-H \mathrm{PdOP}), 6.93(\mathrm{t}, p-H \mathrm{HOPh}) \\
6.84(\mathrm{~d}, o-H \mathrm{HOPh}), 6.57(\mathrm{t}, p-H \mathrm{PdOPh})\end{array}$ & bpy; $8.87\left(\mathrm{dd}, H_{6}\right), 8.08\left(\mathrm{t}, H_{4}\right), 7.97\left(\mathrm{~d}, H_{3}\right), 7.56\left(\mathrm{td}, H_{5}\right)$ \\
\hline 12 & $\begin{array}{l}7.5(\mathrm{~s}, \mathrm{OH}), 7.28(\mathrm{~d}, o-H \mathrm{PdOPh}), 7.20(\mathrm{t}, m-H \mathrm{HOPh}) \\
6.96(\mathrm{t}, m-H \mathrm{PdOP}), 6.89(\mathrm{t}, p-H \mathrm{HOPh}) \\
6.84(\mathrm{~d}, o-H \mathrm{HOPh}), 6.54(\mathrm{t}, p-H \mathrm{PdOPh})\end{array}$ & tmeda; $2.51\left(\mathrm{~s}, \mathrm{NCH}_{3}\right), 2.36\left(\mathrm{~s}, \mathrm{NCH}_{2}\right)$ \\
\hline 13 & $\begin{array}{l}7.3(\mathrm{~s}, \mathrm{OH}), 7.25(\mathrm{~d}, o-H \mathrm{PdOPh}), 7.17(\mathrm{t}, m-H \mathrm{HOPh}) \\
\quad 6.98(\mathrm{t}, p-H \mathrm{HOPh}), 6.87(\mathrm{~d}, o-H \mathrm{HOPh}) \\
6.82(\mathrm{~d}, m-H \mathrm{PdOPh}), 6.53(\mathrm{t}, p-H \mathrm{PdOPh})\end{array}$ & $\begin{array}{l}\text { dpe; } 3.45-3.21\left(\mathrm{~m}, \mathrm{NCH}_{2}\right), 2.77\left(\mathrm{~s}, \mathrm{NCH}_{2}-\mathrm{CH}_{2} \mathrm{~N}\right) \\
\quad 1.60-1.25\left(\mathrm{~m}, \mathrm{CH}_{2}\right)\end{array}$ \\
\hline
\end{tabular}

\begin{abstract}
${ }^{a}$ Measurements at $300 \mathrm{MHz}$ in $\mathrm{CDCl}_{3}$ at room temperature unless denoted otherwise. Abbreviations: br, broad; s, singlet; d, doublet; $\mathrm{t}$, triplet; $\mathrm{m}$, multiplet. Coupling constants within the phenoxide/phenol units: ${ }^{3} J=7-8 \mathrm{~Hz} ;{ }^{4} J=1.5 \mathrm{~Hz} .{ }^{b}$ For bpy or $\mathrm{dmap}: H_{6},{ }^{3} J=6-7 \mathrm{~Hz} ;{ }^{4} J=1 \mathrm{~Hz}$. $\mathrm{H}_{5},{ }^{3} \mathrm{~J}=6-7 \mathrm{~Hz},{ }^{4} \mathrm{~J}=1 \mathrm{~Hz} . \mathrm{H}_{4},{ }^{3} \mathrm{~J}=7-8 \mathrm{~Hz} . \mathrm{H}_{3},{ }^{3} J=7-8 \mathrm{~Hz} .{ }^{c}$ Measured in acetone- $d_{6} .{ }^{d}$ For OCH(CF$)_{2}:{ }^{2} J(\mathrm{~F}, \mathrm{H})=7 \mathrm{~Hz}$.
\end{abstract}

Table 4. ${ }^{13} \mathrm{C}$ NMR Data of Palladium Aryloxides ${ }^{a}$

\begin{tabular}{|c|c|c|}
\hline compound & phenoxide/phenol & $\mathrm{N} \sim \mathrm{N}$ and $\mathrm{HOCH}\left(\mathrm{CF}_{3}\right)_{2}$ \\
\hline 2 & 168.24 (ipso-C), $128.00(\mathrm{~m}-\mathrm{C}), 119.58(o-C), 114.21(p-C)$ & tmeda; $61.88\left(\mathrm{NCH}_{2}\right), 49.91\left(\mathrm{NCH}_{3}\right)$ \\
\hline 3 & $167.92($ ipso-C), $128.47(\mathrm{~m}-\mathrm{C}), 119.40(\mathrm{o}-\mathrm{C}), 113.85(\mathrm{p}-\mathrm{C})$ & teeda; $52.16\left(\mathrm{CH}_{2} \mathrm{CH}_{3}\right), 51.34\left(\mathrm{NCH}_{2}\right), 10.67\left(\mathrm{CH}_{2} \mathrm{CH}_{3}\right)$ \\
\hline 4 & 167.30 (ipso-C), $128.53(\mathrm{~m}-\mathrm{C}), 119.65(\mathrm{o}-\mathrm{C}), 114.20(\mathrm{pC})$ & $\begin{array}{l}\text { dpe; } 55.74\left(\mathrm{NCH}_{2}\right), 53.26\left(\mathrm{~N}\left(\mathrm{CH}_{2}\right)_{2} \mathrm{~N}\right), 23.36\left(\mathrm{~N}\left(\mathrm{CH}_{2}\right)_{2} \mathrm{CH}_{2}\right) \text {, } \\
\quad 19.59\left(\mathrm{NCH}_{2} \mathrm{CH}_{2}\right)\end{array}$ \\
\hline 5 & $\begin{array}{l}167.21(\text { ipso-C), } 166.97 \text { (ipso-C), } 128.78(\mathrm{~m}-\mathrm{C}), 128.70(\mathrm{~m}-\mathrm{C}) \\
\quad 119.90(\mathrm{o}-\mathrm{C}), 119.62(\mathrm{o}-\mathrm{C}), 115.03(\mathrm{p}-\mathrm{C}), 114.78(\mathrm{p}-\mathrm{C})\end{array}$ & $\begin{array}{l}\text { dmap; } 158.65(C 2), 149.40(C 6), 139.32,124.14,121.74 \\
\quad(C 3, C 4, C 5), 69.97\left(\mathrm{NCH}_{2}\right), 50.77\left(\mathrm{NCH}_{3}\right)\end{array}$ \\
\hline 12 & $\begin{array}{l}164.76(\text { ipso- } C \mathrm{PdOPh}), 156.19(\text { ipso- } C \mathrm{HOPh}), 129.57(m-C \mathrm{HOPh}) \\
129.01(m-C \mathrm{PdOPh}), 120.08(o-C \mathrm{HOPh}), 119.92(o-C \mathrm{PdOPh}), \\
116.27(p-C \mathrm{PdOPh}), 115.70(p-C \mathrm{HOPh})\end{array}$ & tmeda; $55.74\left(\mathrm{NCH}_{2}\right), 53.26\left(\mathrm{~N}\left(\mathrm{CH}_{2}\right)_{2} \mathrm{~N}\right)$ \\
\hline 13 & $\begin{array}{l}165.36 \text { (ipso- } C \mathrm{PdOPh}), 156.73 \text { (ipso- } C \mathrm{HOPh}), 129.44(m-C \mathrm{HOPh}) \\
128.73(m-C \mathrm{PdOP}), 119.96(o-C \mathrm{PdOPh}), 119.64(o-C \mathrm{HOPh}), \\
115.80(p-C \mathrm{HOPh}), 115.59(p-C \mathrm{PdOPh})\end{array}$ & $\begin{array}{l}\text { dpe; } 56.00\left(\mathrm{NCH}_{2}\right), 53.27\left(\mathrm{~N}_{\left.\left(\mathrm{CH}_{2}\right)_{2} \mathrm{~N}\right)}\right. \\
23.06\left(\mathrm{~N}\left(\mathrm{CH}_{2}\right)_{2} \mathrm{CH}_{2}\right), 19.57\left(\mathrm{NCH}_{2} \mathrm{CH}_{2}\right)\end{array}$ \\
\hline
\end{tabular}

${ }^{a}$ All measurements at $75 \mathrm{MHz}$ in $\mathrm{CDCl}_{3}$ at room temperature (unless denoted otherwise). No ${ }^{13} \mathrm{C}$ NMR data were obtained for $\mathbf{1}$ and $\mathbf{6}-\mathbf{1 1}$ because of low solubility in organic solvents. ${ }^{b}$ Measured in $\mathrm{CD}_{2} \mathrm{Cl}_{2}$. ${ }^{c}$ For $\mathrm{OCH}\left(\mathrm{CF}_{3}\right)_{2}{ }^{2} \mathrm{~J}(\mathrm{C}, \mathrm{F})=30.0 \mathrm{~Hz}$; $\mathrm{CF}_{3}$ carbon atom not observed.

thermodynamic parameters using this method. Alsters et al. have shown that it is possible to obtain thermodynamic parameters (Scatchard method) for association of phenol to the transbis(phenoxo)palladium(II) complex $\left[\mathrm{Pd}(\mathrm{OPh})_{2}(\text { pyrrolidine })_{2}\right] .{ }^{14 a}$

In the ${ }^{1} \mathrm{H}$ and ${ }^{13} \mathrm{C}$ NMR spectra of the bis(phenol) adducts 11-13, there are separate sets of resonances for the phenoxide ligands and for associated phenol. Compared to 1, 2, and 4, the resonances of the phenoxide in 11-13 are slightly shifted toward those of phenol, and the resonances of the associated phenol are shifted toward those of a phenoxide anion. The ${ }^{1} \mathrm{H}$ NMR data $\left(\mathrm{CDCl}_{3}\right)$ in the temperature range $243-333 \mathrm{~K}$ provide no evidence for exchange between the phenoxide unit and (associated) phenol for these cis-bis(phenoxo)palladium complexes. This means that when exchange is occurring it must be slow on the NMR time scale (see Figure 6). However, phenoxide/phenol exchange is fast on the laboratory time scale; after addition of 2 equiv of pentadeuterophenol to a solution of $\mathbf{1}, \mathbf{2}$, or 4 in $\mathrm{CDCl}_{3}$, the ${ }^{1} \mathrm{H}$ NMR spectrum shows new signals for (associated) phenol and the phenoxide ligand signals are reduced to half their original intensity.

The fluorinated bis(aryloxo)palladium complexes (6-9) when treated with either 1,1,1,3,3,3-hexafluoro-2-propanol or phenol show no evidence for $\mathrm{O}-\mathrm{H} \cdots \mathrm{O}$ hydrogen bonding, with the $\mathrm{O}-\mathrm{H}$ hydrogen of the added alcohol remaining at the resonance position of the free nonassociated alcohol. This result is consistent with the bonding description that fluorine atoms lower the anionic character of the aryloxide ligand (vide supra).

Concluding Remarks. N-donor-ligated palladium(II) complexes containing two aryloxide ligands are easily prepared and prove to be stable in the solid state as well as in solution. They have a tendency to form $\mathrm{O}-\mathrm{H} \cdots \mathrm{O}$ hydrogen bonds in solution, and this indirectly shows that the $\mathrm{Pd}-\mathrm{O}$ bond in these complexes has quite a polar character. In the $\mathrm{C}_{6} \mathrm{~F}_{5} \mathrm{O}^{-}$complexes the presence of fluorine atoms results in the formation of $\pi-\pi$ stacked orientation of the aryloxide rings and also lowers the tendency for adduct formation. These new palladium complexes have potential use as models in various palladium-catalyzed synthetic reactions which involve metal-to-oxygen bonds, and they offer interesting possibilities in the exploration of new stoichiometric and catalytic reactions.

\section{Experimental Procedures}

General Methods. Reactions were performed in an atmosphere of nitrogen using standard Schlenk techniques. Benzene, diethyl ether, 
Table 5. Crystallographic Data for $\mathbf{1}$ and $\mathbf{6}^{a}$

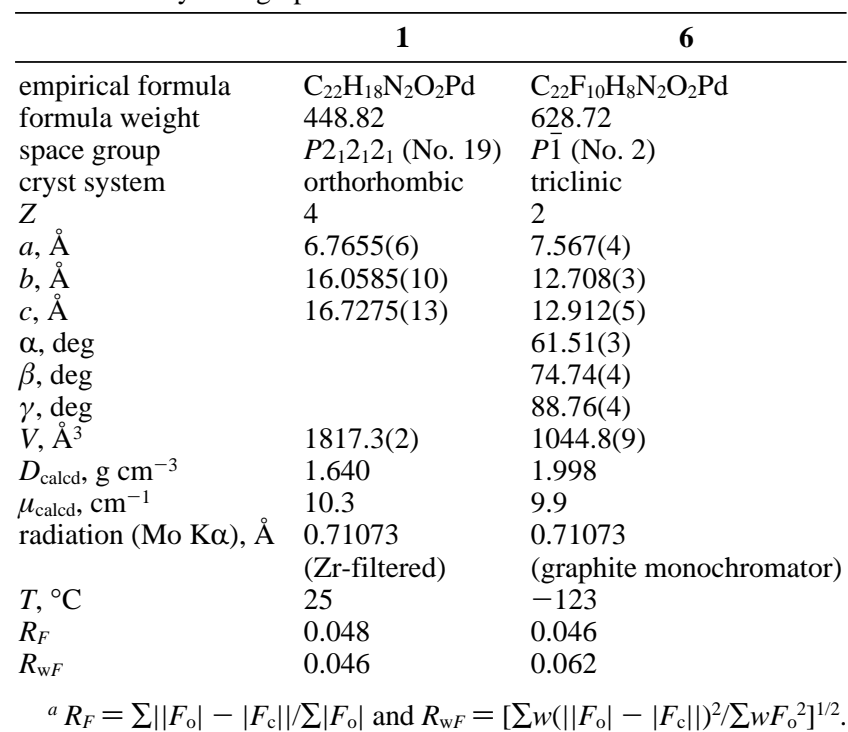

and pentane were freshly distilled from sodium benzophenone ketyl. $\mathrm{CH}_{2} \mathrm{Cl}_{2}$ was distilled from $\mathrm{CaH}_{2}$. All other solvents were used as received. The solvents acetone (p.a) and methanol (p.a) and the materials 1,1,1,3,3,3-hexafluoro-2-propanol, 2,2'-bipyridyl, phenol, pentafluorophenol, and Celite (filter aid) were purchased from Janssen Chimica. ${ }^{1} \mathrm{H}(300.13 \mathrm{MHz})$ and ${ }^{13} \mathrm{C}$ NMR $(75.03 \mathrm{MHz})$ spectra were recorded on a Bruker AC 300 spectrometer at ambient temperature in NMR solvents $\left(\mathrm{CDCl}_{3}, \mathrm{CD}_{2} \mathrm{Cl}_{2}\right.$, and $\left.\mathrm{C}_{6} \mathrm{D}_{6}\right)$ obtained from ISOTEC Inc. ${ }^{1} \mathrm{H}$ and ${ }^{13} \mathrm{C}$ NMR data of the new complexes $\mathbf{1 - 1 3}$ are summarized in Tables 3 and 4, respectively. Infrared spectra (KBr disks) were recorded on a Perkin-Elmer 283 spectrometer. Elemental analyses were carried out by Dornis und Kolbe, Mikroanalytisches Laboratorium, Mülheim a.d. Ruhr, Germany.

[Pd(OPh $\left.)_{2}(\mathbf{b p y})\right]$ (1). To a solution of $\mathrm{Pd}(\mathrm{OAc})_{2}(0.50 \mathrm{~g}, 2.23$ mmol) and bpy $(0.36 \mathrm{~g}, 2.30 \mathrm{mmol})$ in $\mathrm{CH}_{2} \mathrm{Cl}_{2}(50 \mathrm{~mL})$ was added a solution of $\mathrm{NaOPh}(0.52 \mathrm{~g}, 4.50 \mathrm{mmol})$ in a minimum of $\mathrm{MeOH}$ (ca. $5 \mathrm{~mL}$ ). The resulting dark-red mixture was stirred for $1 \mathrm{~h}$, after which the solution was evaporated to dryness under reduced pressure. The residue was extracted with $\mathrm{CH}_{2} \mathrm{Cl}_{2}(8 \times 50 \mathrm{~mL})$, and the extracts were filtered over Celite. The orange filtrate was evaporated to dryness, and the solid product was washed with pentane and dried in vacuo. The solid can be crystallized by diffusion of $\mathrm{Et}_{2} \mathrm{O}$ into a $\mathrm{CH}_{2} \mathrm{Cl}_{2}$ solution. The resulting reddish-brown, needle-shaped crystals are suitable for X-ray diffraction. Yield: $0.82 \mathrm{~g}(82 \%)$. Mp: $202{ }^{\circ} \mathrm{C} \mathrm{dec}$. Anal. Calcd for $\mathrm{C}_{22} \mathrm{H}_{18} \mathrm{~N}_{2} \mathrm{O}_{2} \mathrm{Pd}$ : C, 58.87; H, 4.04; N, 6.24. Found: C, 59.56; H, 4.28; N, 6.23.

$\left[\operatorname{Pd}(\mathrm{OPh})_{2}(\mathrm{~N} \sim \mathrm{N})\right](\mathrm{N} \sim \mathrm{N}=\operatorname{tmeda}(2)$; teeda (3), dpe (4), dmap (5)). Complexes 2-5 were prepared in 85-95\% yield as an orange material as described for synthesis of $\mathbf{1}$, but using tmeda, dmap, or dpe as the ligand. The complexes $\mathbf{2}-\mathbf{5}$ have a better solubility in $\mathrm{CH}_{2}$ $\mathrm{Cl}_{2}$ than 1. $\mathrm{Mp}$ for 2: $172{ }^{\circ} \mathrm{C} \mathrm{dec}$. Mp for 3: $170{ }^{\circ} \mathrm{C} \mathrm{dec}$. Mp for 4: $171{ }^{\circ} \mathrm{C}$ dec. $\mathrm{Mp}$ for 5: $139{ }^{\circ} \mathrm{C}$ dec. Anal. Calcd for $\mathrm{C}_{18} \mathrm{H}_{26} \mathrm{~N}_{2} \mathrm{O}_{2} \mathrm{Pd}$ (2): C, 52.87; H, 6.24; N, 6.85. Found: C, 52.69; H, 6.47; N, 6.94. Anal. Calcd for $\mathrm{C}_{22} \mathrm{H}_{34} \mathrm{~N}_{2} \mathrm{O}_{2} \mathrm{Pd}(3)$ : C, 56.88; H, 7.40; N, 6.23. Found: C, 56.83; H, 7.37; N, 6.03. Anal. Calcd for $\mathrm{C}_{24} \mathrm{H}_{34} \mathrm{~N}_{2} \mathrm{O}_{2} \mathrm{Pd}$ (4): C, 58.95; H, 7.01; N, 5.73. Found: C, 59.09; H, 7.11; N, 5.79. Anal. Calcd for $\mathrm{C}_{20} \mathrm{H}_{22} \mathrm{~N}_{2} \mathrm{O}_{2} \mathrm{Pd}(5)$ : C, 55.18; H, 5.16; N, 6.40. Found: C, 54.92; H, 5.42; N, 6.29.

$\left[\mathbf{P d}\left(\mathbf{O C}_{\mathbf{6}} \mathbf{F}_{5}\right)_{2}(\mathbf{b p y})\right](\mathbf{6})$. To a stirred suspension of $\mathbf{1}(0.20 \mathrm{~g}, 0.45$ $\mathrm{mmol})$ in $\mathrm{CH}_{2} \mathrm{Cl}_{2}(15 \mathrm{~mL})$ was added pentafluorophenol $(0.41 \mathrm{~g}, 2.25$ $\mathrm{mmol})$. After $1 \mathrm{~h}$ the yellow solution was filtered over Celite, and the filtrate was evaporated to a small volume $(\mathrm{ca} .3 \mathrm{~mL})$. The pure product was obtained by diffusion of pentane into this solution. The resulting long, needle-shaped dark-yellow crystals (suitable for X-ray diffraction) were washed with pentane $(3 \times 10 \mathrm{~mL})$ and dried in vacuo. Yield: $0.27 \mathrm{~g}(95 \%)$. Mp: $224{ }^{\circ} \mathrm{C}$ dec. Anal. Calcd for $\mathrm{C}_{22} \mathrm{H}_{8} \mathrm{~F}_{10} \mathrm{~N}_{2} \mathrm{O}_{2} \mathrm{Pd}$ : C, 42.03; H, 1.28; N, 4.46. Found: C, 41.94; H, 1.35; N, 4.52.

$\left[\operatorname{Pd}\left(\mathrm{OC}_{6} \mathbf{F}_{5}\right)_{2}(\mathbf{N} \sim \mathbf{N})\right](\mathbf{N} \sim \mathbf{N}=\operatorname{tmeda}(7)$, dpe (8), dmap (9)). Complexes 7-9 were prepared in $85-95 \%$ yield as a yellow material
Table 6. Final Coordinates and Equivalent Isotropic Thermal Parameters of the Non-Hydrogen Atoms for $\mathbf{1}$

\begin{tabular}{llccl}
\hline atom & \multicolumn{1}{c}{$x$} & $y$ & $z$ & $U_{\mathrm{eq}}\left(\AA^{2}\right)^{a}$ \\
\hline $\mathrm{Pd}$ & $0.02855(11)$ & $0.18551(5)$ & $0.14770(5)$ & $0.0384(2)$ \\
$\mathrm{O}(1)$ & $0.0747(11)$ & $0.2061(5)$ & $0.2639(4)$ & $0.051(3)$ \\
$\mathrm{O}(2)$ & $0.0078(11)$ & $0.0631(4)$ & $0.1611(4)$ & $0.051(3)$ \\
$\mathrm{N}(1)$ & $0.0238(13)$ & $0.3078(5)$ & $0.1236(4)$ & $0.043(3)$ \\
$\mathrm{N}(2)$ & $0.0135(11)$ & $0.1783(5)$ & $0.0277(4)$ & $0.040(3)$ \\
$\mathrm{C}(1)$ & $-0.0637(17)$ & $0.1882(8)$ & $0.3179(6)$ & $0.047(3)$ \\
$\mathrm{C}(2)$ & $-0.015(2)$ & $0.1980(7)$ & $0.3981(6)$ & $0.055(4)$ \\
$\mathrm{C}(3)$ & $-0.153(2)$ & $0.1842(7)$ & $0.4575(6)$ & $0.066(5)$ \\
$\mathrm{C}(4)$ & $-0.340(2)$ & $0.1576(7)$ & $0.4390(7)$ & $0.069(6)$ \\
$\mathrm{C}(5)$ & $-0.392(2)$ & $0.1498(7)$ & $0.3598(7)$ & $0.067(5)$ \\
$\mathrm{C}(6)$ & $-0.2522(18)$ & $0.1641(6)$ & $0.3002(6)$ & $0.050(4)$ \\
$\mathrm{C}(7)$ & $0.1713(17)$ & $0.0170(6)$ & $0.1621(6)$ & $0.042(4)$ \\
$\mathrm{C}(8)$ & $0.1650(19)$ & $-0.0649(7)$ & $0.1305(6)$ & $0.056(4)$ \\
$\mathrm{C}(9)$ & $0.327(2)$ & $-0.1142(7)$ & $0.1309(7)$ & $0.064(5)$ \\
$\mathrm{C}(10)$ & $0.503(2)$ & $-0.0868(7)$ & $0.1605(6)$ & $0.060(4)$ \\
$\mathrm{C}(11)$ & $0.517(2)$ & $-0.0079(7)$ & $0.1907(6)$ & $0.059(4)$ \\
$\mathrm{C}(12)$ & $0.3507(17)$ & $0.0439(7)$ & $0.1928(6)$ & $0.046(4)$ \\
$\mathrm{C}(13)$ & $0.0258(16)$ & $0.3681(6)$ & $0.1771(6)$ & $0.047(3)$ \\
$\mathrm{C}(14)$ & $0.0170(19)$ & $0.4506(7)$ & $0.1557(7)$ & $0.066(4)$ \\
$\mathrm{C}(15)$ & $0.0117(18)$ & $0.4706(6)$ & $0.0755(7)$ & $0.058(4)$ \\
$\mathrm{C}(16)$ & $0.0107(16)$ & $0.4087(7)$ & $0.0183(6)$ & $0.050(4)$ \\
$\mathrm{C}(17)$ & $0.0183(14)$ & $0.3268(6)$ & $0.0437(6)$ & $0.040(3)$ \\
$\mathrm{C}(18)$ & $0.0138(18)$ & $0.2534(7)$ & $-0.0090(6)$ & $0.043(3)$ \\
$\mathrm{C}(19)$ & $0.0185(19)$ & $0.2577(7)$ & $-0.0920(6)$ & $0.050(4)$ \\
$\mathrm{C}(20)$ & $0.0203(15)$ & $0.1874(8)$ & $-0.1359(6)$ & $0.058(4)$ \\
$\mathrm{C}(21)$ & $0.014(2)$ & $0.1101(8)$ & $-0.0997(6)$ & $0.060(5)$ \\
$\mathrm{C}(22)$ & $0.0100(19)$ & $0.1078(7)$ & $-0.0167(6)$ & $0.053(4)$ \\
& & & &
\end{tabular}

${ }^{a} U_{\mathrm{eq}}=1 / 3$ of the trace of the orthogonalized $\mathbf{U}$ tensor.

as described for $\mathbf{6}$, but starting from $\mathbf{2}, \mathbf{4}$, or $\mathbf{5}$ in place of $\mathbf{1}$. Mp for 7: $210^{\circ} \mathrm{C}$ dec. $\mathrm{Mp}$ for 8: $184^{\circ} \mathrm{C} \mathrm{dec}$. Mp for 9: $152^{\circ} \mathrm{C} \mathrm{dec}$. Anal. Calcd for $\mathrm{C}_{18} \mathrm{H}_{16} \mathrm{~F}_{10} \mathrm{~N}_{2} \mathrm{O}_{2} \mathrm{Pd}(7)$ : C, 36.72; H, 2.74; N, 4.76. Found: C, 36.70; H, 2.77; N, 4.72. Anal. Calcd for $\mathrm{C}_{20} \mathrm{H}_{12} \mathrm{~N}_{2} \mathrm{~F}_{10} \mathrm{O}_{2} \mathrm{Pd}(9)$ : C, 39.46; H, 1.99; N, 4.60. Found: C, 39.62; H, 1.91; N, 4.71.

$\left[\operatorname{Pd}\left(\mathrm{OCH}\left(\mathrm{CF}_{3}\right)_{2}\right)(\mathrm{OPh})(\mathbf{b p y})\right] \cdot \mathbf{H O P h}(\mathbf{1 0})$. To a stirred suspension of $1(0.20 \mathrm{~g}, 0.45 \mathrm{mmol})$ in $\mathrm{CH}_{2} \mathrm{Cl}_{2}(15 \mathrm{~mL})$ was added $1,1,1,3,3,3$ hexafluoro-2-propanol $(0.38 \mathrm{~g}, 2.25 \mathrm{mmol})$. After $1 \mathrm{~h}$ the yellow solution was filtered off over Celite and evaporated to a small volume (ca. $5 \mathrm{~mL}$ ). The pure product was obtained by diffusion of pentane into this solution. The resulting long, needle-shaped yellow crystals (suitable for X-ray diffraction; see ref $14 \mathrm{~b}$ ) were washed with pentane $(3 \times 10 \mathrm{~mL})$ and dried in vacuo. Yield: $0.22 \mathrm{~g}(81 \%) . \mathrm{Mp}: 192{ }^{\circ} \mathrm{C}$ dec. Anal. Calcd for $\mathrm{C}_{19} \mathrm{H}_{14} \mathrm{~F}_{6} \mathrm{~N}_{2} \mathrm{O}_{2} \mathrm{Pd}$ : C, 43.66; H, 2.70; N, 5.36. Found: C, 42.92; H, 2.74; N, 5.62.

Reactions of 1, 2, and 4 with Phenol (in Situ Preparation of the Adducts $\left[\operatorname{Pd}(\mathrm{OPh})_{2}(\mathrm{~N} \sim \mathrm{N})\right] \cdot 2 \mathrm{HOPh}(\mathrm{N} \sim \mathrm{N}=$ bpy (11), tmeda (12), dpe (13)). A solution of 1, 2, or 4 in $\mathrm{CDCl}_{3}(0.5 \mathrm{~mL}$, dried over calcium chloride) was transferred to an NMR tube containing 2 equiv of phenol. ${ }^{1} \mathrm{H}$ and ${ }^{13} \mathrm{C}$ NMR data indicate the quantitative formation of the bis(phenol) adducts $\mathbf{1 1}, \mathbf{1 2}$, and $\mathbf{1 3}$, respectively. Due to the low solubility of 11 in $\mathrm{CDCl}_{3}$, no ${ }^{13} \mathrm{C} \mathrm{NMR}$ data was obtained for this adduct. All attempts to isolate these $\mathrm{O}-\mathrm{H} \cdots \mathrm{O}$ hydrogen-bonded species failed, and during crystallization the starting materials were regenerated.

Crystal Structure Determination of $\left[\mathrm{Pd}(\mathrm{OPh})_{2}(\mathrm{bpy})\right](1) . \quad \mathrm{A}$ reddish-brown, block-shaped crystal $(0.12 \times 0.18 \times 0.50 \mathrm{~mm})$ was glued to the tip of a glass fiber and transferred to an Enraf-Nonius CAD4-F diffractometer. Accurate unit cell parameters and an orientation matrix were determined by least-squares refinement of 25 wellcentered reflections (SET4) in the range $8.0^{\circ}<\theta<13.0^{\circ}$. Reducedcell calculations did not indicate higher lattice symmetry. ${ }^{24}$ Crystal data and details on data collection and refinement are presented in Table 5. Data were collected at ambient temperature in $\omega / 2 \theta$ mode with scan angle $\Delta \omega=0.81+0.35 \tan \theta^{\circ}$. Intensity data of 3107 reflections were collected in the range $1.21^{\circ}<\theta<27.50^{\circ}$; of these 2938 are independent. Data were corrected for Lorentz-polarization effects. Three periodically measured reference reflections $(\overline{2} 11,220,172)$ showed no significant decay $(<1 \%)$ during $45 \mathrm{~h}$ of X-ray exposure

(24) Spek, A. L. J. Appl. Crystallogr. 1988, 21, 578. 
time. Standard deviations of the intensities as obtained by counting statistics were increased according to an analysis of the excess variance of the reference reflections: $\sigma^{2}(I)=\sigma_{\text {cs }}^{2}(I)+(0.008 I)^{2} .{ }^{25}$ An empirical absorption extinction correction was applied (DIFABS, ${ }^{26}$ correction range $0.762-1.115)$. The structure was solved by automated direct methods (SHELXS86). ${ }^{27}$ Refinement of $F$ was carried out by fullmatrix least-squares techniques (SHELX76). ${ }^{28}$ Hydrogen atoms were included in the refinement on calculated positions $(\mathrm{C}-\mathrm{H}=0.98 \AA)$ riding on their carrier atoms. All non-hydrogen atoms were refined with anisotropic thermal parameters; the hydrogen atoms were refined with one overall isotropic thermal parameter of $0.065(8) \AA^{2}$. Weights were introduced in the final refinement cycles. Convergence was reached at $R=0.048, R_{\mathrm{w}}=0.046, w=1 /\left[\sigma^{2}(F)+0.00046 F^{2}\right], S=$ 1.79 , for 245 parameters and 1536 reflections with $I>2.5 \sigma(I)$. A final difference Fourier map showed no residual density outside -0.72

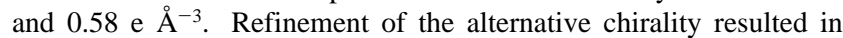
slightly higher values of $R$ and $R_{\mathrm{w}}(0.055$ and 0.051 , respectively). Positional parameters are listed in Table 6.

Crystal Structure Determination of $\left[\operatorname{Pd}\left(\mathrm{OC}_{6} \mathbf{F}_{5}\right)_{2}(\mathbf{b p y})\right](6)$. A dark-yellow, needle-shaped crystal $(0.1 \times 0.1 \times 1.2 \mathrm{~mm})$ was glued to the tip of a glass fiber and transferred into the cold nitrogen stream of an Enraf-Nonius CAD4-Turbo diffractometer with rotating anode. Final lattice parameters were determined by least-squares treatment, using the setting angles (SET4) of 25 well-centered reflections in the range $10.0^{\circ}<\theta<13.9^{\circ}$. The unit cell parameters were checked for the presence of higher lattice symmetry. ${ }^{24}$ Crystal data and details on data collection and refinement are collected in Table 5. Data were collected at $150 \mathrm{~K}$ in $\omega / 2 \theta$ mode with scan angle $\Delta \omega=1.57+0.35$ $\tan \theta^{\circ}$. From a total of 3869 reflections in the range $1.83^{\circ}<\theta<$ $25.38^{\circ}$ (3569 unique), 3161 satisfied the $I>2.5 \sigma(I)$ criterion of observability. Data were corrected for Lorentz-polarization effects and for a decay of $3 \%$ of the three periodically measured reference reflections $(\overline{2} 0 \overline{5}, 12 \overline{3}, 342)$ during $25 \mathrm{~h}$ of X-ray exposure time. An empirical absorption extinction correction was applied (DIFABS, ${ }^{26}$ correction range $0.800-1.218$ ). The structure was solved by automated direct methods (SHELXS86). ${ }^{27}$ Refinement on $F$ was carried out by full-matrix least-squares techniques (SHELX76). ${ }^{28}$ Hydrogen atoms were included in the refinement on calculated positions $(\mathrm{C}-\mathrm{H}=0.98$ $\AA$ ) riding on their carrier atoms. All non-hydrogen atoms were refined with anisotropic thermal parameters; the hydrogen atoms were refined with one overall isotropic thermal parameter of $0.030(6) \AA^{2}$. Weights were introduced in the final refinement cycles. Convergence was reached at $R=0.046, R_{\mathrm{w}}=0.062, w=1 /\left[\sigma^{2}(F)+0.0001365 F^{2}\right], S=$ 1.48 , for 335 parameters. A final difference Fourier map showed no residual density outside -1.44 and 1.38 e $\AA^{-3}$ (near Pd), probably absorption artifacts. Final positional parameters are listed in Table 7.

(25) McCandish, L. E.; Stout, G. H.; Andrews, L. C. Acta Crystallogr. 1975, A31, 245.

(26) Walker, N.; Stuart, D. Acta Crystallogr. 1983, A39, 158.

(27) Sheldrick, G. M. SHELXS86. Program for crystal structure determination. University of Göttingen, Germany, 1986.

(28) Sheldrick, G. M. SHELX76. Program for crystal structure determination. University of Cambridge, Cambridge, 1976.
Table 7. Final Coordinates and Equivalent Isotropic Thermal Parameters of the Non-Hydrogen Atoms for $\mathbf{6}$

\begin{tabular}{lrrrr}
\hline atom & \multicolumn{1}{c}{$x$} & $y$ & $z$ & $U_{\mathrm{eq}}\left(\AA^{2}\right)^{a}$ \\
\hline $\mathrm{Pd}(1)$ & $0.21568(5)$ & $0.41384(3)$ & $0.39831(3)$ & $0.0156(1)$ \\
$\mathrm{F}(1)$ & $0.6537(4)$ & $0.4104(3)$ & $0.2060(3)$ & $0.0313(10)$ \\
$\mathrm{F}(2)$ & $0.7803(4)$ & $0.2724(3)$ & $0.1007(3)$ & $0.0329(10)$ \\
$\mathrm{F}(3)$ & $0.5651(5)$ & $0.1994(3)$ & $0.0032(3)$ & $0.0329(10)$ \\
$\mathrm{F}(4)$ & $0.2234(5)$ & $0.2677(3)$ & $0.0081(3)$ & $0.0332(11)$ \\
$\mathrm{F}(5)$ & $0.0937(4)$ & $0.4049(3)$ & $0.1133(3)$ & $0.0312(10)$ \\
$\mathrm{F}(6)$ & $0.3974(4)$ & $0.1853(3)$ & $0.4297(3)$ & $0.0259(9)$ \\
$\mathrm{F}(7)$ & $0.4902(4)$ & $0.0338(3)$ & $0.3393(3)$ & $0.0284(9)$ \\
$\mathrm{F}(8)$ & $0.2451(4)$ & $-0.0471(3)$ & $0.2635(3)$ & $0.0304(10)$ \\
$\mathrm{F}(9)$ & $-0.0998(4)$ & $0.0220(3)$ & $0.2863(3)$ & $0.0312(10)$ \\
$\mathrm{F}(10)$ & $-0.1912(4)$ & $0.1798(3)$ & $0.3704(3)$ & $0.0267(9)$ \\
$\mathrm{O}(1)$ & $0.3066(6)$ & $0.4779(3)$ & $0.2153(3)$ & $0.0282(11)$ \\
$\mathrm{O}(2)$ & $0.0527(5)$ & $0.2670(3)$ & $0.4417(3)$ & $0.0241(11)$ \\
$\mathrm{N}(1)$ & $0.3436(6)$ & $0.5597(4)$ & $0.3796(4)$ & $0.0206(12)$ \\
$\mathrm{N}(2)$ & $0.1294(6)$ & $0.3801(4)$ & $0.5726(4)$ & $0.0192(12)$ \\
$\mathrm{C}(1)$ & $0.3687(7)$ & $0.4105(4)$ & $0.1656(4)$ & $0.0195(14)$ \\
$\mathrm{C}(2)$ & $0.5449(7)$ & $0.3747(5)$ & $0.1578(4)$ & $0.0219(16)$ \\
$\mathrm{C}(3)$ & $0.6125(7)$ & $0.3046(5)$ & $0.1053(4)$ & $0.0211(14)$ \\
$\mathrm{C}(4)$ & $0.5027(7)$ & $0.2699(4)$ & $0.0538(4)$ & $0.0219(14)$ \\
$\mathrm{C}(5)$ & $0.3295(7)$ & $0.3037(5)$ & $0.0578(4)$ & $0.0216(16)$ \\
$\mathrm{C}(6)$ & $0.2641(7)$ & $0.3730(5)$ & $0.1105(4)$ & $0.0209(16)$ \\
$\mathrm{C}(7)$ & $0.1014(7)$ & $0.1906(4)$ & $0.4013(4)$ & $0.0189(12)$ \\
$\mathrm{C}(8)$ & $0.2714(7)$ & $0.1475(4)$ & $0.3937(4)$ & $0.0203(14)$ \\
$\mathrm{C}(9)$ & $0.3206(7)$ & $0.0685(4)$ & $0.3491(4)$ & $0.0209(14)$ \\
$\mathrm{C}(10)$ & $0.1960(7)$ & $0.0270(4)$ & $0.3109(5)$ & $0.0216(14)$ \\
$\mathrm{C}(11)$ & $0.0243(7)$ & $0.0644(4)$ & $0.3208(4)$ & $0.0200(14)$ \\
$\mathrm{C}(12)$ & $-0.0214(7)$ & $0.1442(4)$ & $0.3630(4)$ & $0.0188(14)$ \\
${ }^{a} U_{\text {eq }}=1 / 3$ of the trace of the orthogonalized U tensor. &
\end{tabular}

Neutral atom scattering factors were taken from Cromer and Mann, ${ }^{29}$ and anomalous dispersion corrections were taken from Cromer and Liberman. ${ }^{30}$ Geometrical calculations and illustrations were performed with PLATON. ${ }^{31}$ All calculations were performed on a DECstation $5000 / 125$

Crystal Structure Determination of 10. See ref $14 \mathrm{~b}$.

Acknowledgment. Shell Research B.V. is gratefully thanked (G.M.K.) for financial support. The investigations were supported in part (A.L.S., W.J.J.S.) by the Netherlands Foundation for Scientific Research (SON) with financial aid from the Netherlands Organization for Scientific Research (NWO).

Supporting Information Available: Further details of the structure determinations, including listings of atomic coordinates, bond lengths and angles, and thermal parameters for 1 and $\mathbf{6}$ (12 pages). Ordering information is given on any current masthead page.

\section{IC950563P}

(29) Cromer, D. T.; Mann, J. B. Acta Crystallogr. 1968, A24, 321.

(30) Cromer, D. T.; Liberman, D. J. Chem. Phys. 1970, 53, 1891.

(31) Spek, A. L. Acta Crystallogr. 1990, A46, C34. 